\title{
Effect of the Ethyl Acetate Fraction of Eugenia uniflora on Proteins Global Expression during Morphogenesis in Candida albicans
}

\author{
Walicyranison P. Silva-Rocha ${ }^{1}$, Matheus F. de Azevedo', Magda R. A. Ferreira', \\ Julhiany de Fátima da Silva ${ }^{3}$, Terezinha I. E. Svidzinski ${ }^{4}$, Eveline P. Milan ${ }^{5}$, \\ Luiz A. L. Soares ${ }^{2}$, Keyla B. F. Rocha ${ }^{6}$, Adriana F. Uchôa ${ }^{7}$, Maria J. S. Mendes-Giannini ${ }^{3}$, \\ Ana M. Fusco Almeida ${ }^{3}$ and Guilherme M. Chaves ${ }^{1 *}$ \\ ${ }^{1}$ Laboratório de Micologia Médica e Molecular, Departamento de Análises Clínicas e Toxicológicas, Universidade Federal do \\ Rio Grande do Norte, Natal, Brazil, ${ }^{2}$ Departamento de Farmácia, Centro de Ciências da Saúde, Universidade Federal de \\ Pernambuco, Recife, Brazil, ${ }^{3}$ Faculdade de Ciências Farmacêuticas, Universidade Estadual Paulista, São Paulo, Brazil, \\ ${ }^{4}$ Departamento de Análise Clínicas, Centro de Ciências Biológicas, Universidade Estadual de Maringá, Maringá, Brazil, \\ ${ }^{5}$ Departamento de Infectologia, Centro de Ciências da Saúde, Universidade Federal do Rio Grande do Norte, Natal, Brazil, \\ ${ }^{6}$ Departamento de Patologia, Centro de Ciências da Saúde, Universidade Federal do Rio Grande do Norte, Natal, Brazil, \\ ${ }^{7}$ Departamento de Biologia Celular e Genética, Centro de Biociências, Instituto de Medicina Tropical do RN, Universidade \\ Federal do Rio Grande do Norte, Natal, Brazil
}

\section{OPEN ACCESS}

Edited by:

Dominique Sanglard,

University of Lausanne, Switzerland

Reviewed by:

Rodnei Dennis Rossoni, São Paulo State University, Brazi

Malcolm Whiteway, Concordia University, Canada

*Correspondence: Guilherme M. Chaves guilherme.chaves@ufrnet.br

Specialty section This article was submitted to Fungi and Their Interactions,

a section of the journal

Frontiers in Microbiology

Received: 29 May 2017 Accepted: 05 September 2017 Published: 26 September 2017

Citation:

Silva-Rocha WP, de Azevedo MF,

Ferreira MRA, da Silva JdF, Svidzinski TIE, Milan EP, Soares LAL,

Rocha KBF, Uchôa $A F$,

Mendes-Giannini MJS, Fusco Almeida AM and Chaves GM (2017) Effect of the Ethyl Acetate Fraction of Eugenia uniflora on Proteins Global Expression during Morphogenesis in Candida albicans.

Front. Microbiol. 8:1788.

doi: 10.3389/fmich.2017.01788
Candida albicans is able to switch from yeast to hyphal growth and this is an essential step for tissue invasion and establishment of infection. Due to the limited drug arsenal used to treat fungal infections and the constant emergence of resistant strains, it is important to search for new therapeutic candidates. Therefore, this study aimed to investigate by proteomic analysis the role of a natural product (Eugenia uniflora) in impairing hypha formation in C. albicans. We also tested the potential action of $E$. uniflora to prevent and treat oral candidiasis induced in a murine model of oral infection and the ability of polymorphonuclear neutrophils to phagocytize $C$. albicans cells treated with the ethyl acetate fraction of the extract. We found that this fraction greatly reduced hypha formation after morphogenesis induction in the presence of serum. Besides, several proteins were differentially expressed in cells treated with the fraction. Surprisingly, the ethyl acetate fraction significantly reduced phagocytosis in C. albicans (Mean 120.36 \pm 36.71 yeasts/100 PMNs vs. $44.68 \pm 19.84$ yeasts/100 PMNs). Oral candidiasis was attenuated when $C$. albicans cells were either pre-incubated in the presence of $E$. uniflora or when the fraction was applied to the surface of the oral cavity after infection. These results were consistent with the reduction in CFU counts (2.36 vs. $1.85 \mathrm{Log} 10 \mathrm{CFU} / \mathrm{ml}$ ) and attenuation of tissue damage observed with histopathological analysis of animals belonging to treated group. We also observed shorter true hyphae by direct examination and histopathological analysis, when cells were treated with the referred natural product. The E. uniflora ethyl acetate fraction was non-toxic to human cells. E. uniflora may act on essential proteins mainly related to cellular structure, reducing the capacity of filamentation and attenuating infection in a murine model, without causing any toxic effect on human cells, suggesting that it may be a future therapeutic alternative for the treatment of Candida infections.

Keywords: Candida albicans, phagocytosis, morphogenesis, proteomics, Eugenia uniflora, murine model 


\section{INTRODUCTION}

Although some Candida species, mainly C. albicans belong to the normal human microbiota, they may become pathogenic in some circumstances, depending on host immunological conditions associated with virulence factors expressed by these microorganisms (Chaves et al., 2012; Younes and Khalaf, 2013). C. albicans is associated with superficial and systemic infections, and may cause life threatening diseases including candidemia, whose mortality rate is about 40-60\% (Nucci et al., 2013).

Although Candida spp. live as commensals in the oral cavity of $30-60 \%$ of healthy individuals, these yeasts are capable of causing infection in the presence of predisposing conditions of the host, such as some environmental changes, which include a salivary gland dysfunction affecting the quantity and quality of saliva (Patil et al., 2015), the use of dental prosthesis, mainly of acrylic material, the presence of nutritional deficiencies, high carbohydrate diets, systemic diseases that may lead to imunnossupression, the use of immunosuppressive agents and organ transplantation (Sherman et al., 2002; Colombo et al., 2007; Muzyka and Epifanio, 2013; Nucci et al., 2013).

Oral candidiasis is frequently associated with high morbidity due the aspect of chronic pain which occurs in most cases, causing a discomfort upon mastication, which considerably alters the nutrition of individuals, mainly in the elderly and immunocompromised patients (Sherman et al., 2002).

Several virulence factors are associated with $C$. albicans pathogenicity, which contribute to the establishment of infection, including the ability to adhere to epithelial cells, the secretion of hydrolytic enzymes, biofilm formation and the transition of yeast cells to filamentous forms, which is known as morphogenesis (Silva-Rocha et al., 2015).

Another important virulence factor of C. albicans is the ability to combat reactive oxygen species (ROS) generated inside mammalian phagocytic cells, specifically polymorphonuclear neutrophils (PMNs; Marcos et al., 2016). Therefore, phagocytosis is the first line of defense against $C$. albicans invasion, and is performed by innate immune cells such as macrophage and neutrophils in healthy individuals (Dantas Ada et al., 2015) Neutropenia is a major risk factor for the establishment of Candida infections (Becker et al., 2015).

C. albicans resistance to phagocytosis by PMNs is due to the arsenal of enzymes produced by this yeast such as catalase, superoxide dismutase, glutathione reductase, which degrade reactive oxygen species produced by the immune host cells (Chaves et al., 2007; Herrero et al., 2008; Chaves and da Silva, 2012) and the ability to switch from budding to filamentous cells, which may cause a PMN membrane rupture allowing C. albicans to escape from PMNs killing (Dantas Ada et al., 2015).

Several studies related to morphogenesis in C. albicans were developed using mutant strains, whose genes that encode proteins responsible for these metabolic pathways, are attenuated in host tissue damage and virulence (Gow et al., 2012; Tsang et al., 2012). Jayatilake et al. (2006) demonstrated that C. albicans $\Delta c p h 1 / c p h 1$, a mutant with reduced ability of hypha formation, showed weaker tissue invasion and damage in a reconstituted oral epithelium model of infection, when compared to the wild type strain.

In the formation of true hyphae, an apical growth occurs to form tubular structures in the presence of parallels walls (Carlisle and Kadosh, 2013). The structures of filamentation in C. albicans are produced after the expression of several genes related to morphogenesis as well as by other co-regulated genes associated with other virulence factors, such as adherence and biofilm formation (Samaranayake et al., 2013; Childers and Kadosh, 2015). Morphogenesis is essential for the process of tissue invasion and thus the establishment of infection (Samaranayake et al., 2013; Childers and Kadosh, 2015).

The recent increase of antifungal resistance and the reduced therapeutic arsenal of drugs available in the management of fungal infections are still aggregated with other relevant problem that is the toxicity present in some classical antifungal drugs, such as amphotericin B, which causes renal toxicity (Hamill, 2013). Therefore, the investigation of natural products and their derived extracts from various vegetal parts (leaves, fruit, roots) for the purpose of seeking new compounds with antimicrobial properties has steadily increased recently (Amorim et al., 2009).

Eugenia uniflora, a widely distributed plant in South America, especially in Brazil, Argentina, Uruguay and Paraguay, is a tropical plant belonging to the family Myrtaceae and is popularly known as "pitangueira" in Brazil (Amorim et al., 2009). This plant family has more than 500 species, where 400 are natives of Brazil (Schumacher et al., 2015). It includes vegetables that have phenolic compounds with antioxidant and some with hypoglycemic and antirheumatic action, also used for stomach ailments and as antihypertensive (Amorim et al., 2009; SilvaRocha et al., 2015). This natural product has also antimicrobial activity. This property was observed with its essential oil against Staphylococcus aureus, Listeria monocytogenes and Candida spp. (Victoria et al., 2012). The antifungal activity of several E. uniflora leaf fraction extracts were also observed against Trichophyton rubrum and T. mentagrophytes (Biasi-Garbin et al., 2016) and Candida species (Ferreira et al., 2013). Therefore, we used the ethyl acetate (EAF) fraction of this natural product by obtaining a fraction enriched in polyphenols. According to Ramos et al. (2017), the fraction has a flavonoid content about 9 times higher than the crude extract and this enrichment showed better anti-Candida activity. We decided to investigate whether this fraction, in addition to inhibiting fungal growth, could interact directly with the expression of virulence factors, specifically morphogenesis in C. albicans.

By evaluating transcriptional and proteomic responses to carbon starvation in Paracoccidioides, Lima et al. (2014) found that $86 \%$ of the matches showed the same pattern of transcripts and protein levels. Therefore, although we recognize that transcriptomics is more sensitive and comprehensive to study expression patterns, and that sometimes transcripts and proteins do not follow the same trend of expression that could be explained, for example, by mRNA stabilization process or by active post-transcriptional and translational regulatory mechanisms, proteomics may be a suitable and alternative less costly technique to study differential expression in fungi 
including C. albicans (Martínez-Gomariz et al., 2009; Gil-Bona et al., 2015).

Therefore, this study aimed to investigate which proteins are differentially expressed during filamentation when morphogenesis in C. albicans is induced in the presence of serum, after cell growth in the presence of the E. uniflora ethyl EAF. We also evaluated the direct interaction of the natural product with PMNs phagocytosis and performed a murine model of oral candidiasis in the presence of the referred fraction.

\section{MATERIALS AND METHODS}

\section{Obtaining an Enriched Fraction of Eugenia uniflora Linn Leaves}

The crude extract of E. uniflora leaves was obtained at $10 \%$ $(\mathrm{w} / \mathrm{v})$ with acetone: water $(7: 3, \mathrm{v} / \mathrm{v})$ by turbo extraction in four rounds of $5 \mathrm{~min}$. The extract was filtered and concentrated by rotary evaporation at $40^{\circ} \mathrm{C}\left(\mathrm{RV} 10\right.$ Basic, IKA $\left.{ }^{\circledR}\right)$. The residue was frozen $\left(-80^{\circ} \mathrm{C}, 3\right.$ days) and then lyophilized (Model L101, Liotop ${ }^{\circledR}$ ) to yield a Crude Extract (CE). Approximately $20 \mathrm{~g}$ of $\mathrm{CE}$ were reconstituted in water $(200 \mathrm{~mL})$ and this solution was fractionated six times with $20 \mathrm{~mL}$ hexane. The resulting aqueous fraction was partitioned twelve more times with $20 \mathrm{~mL}$ ethyl acetate. This ethyl acetate fraction (EAF) was concentrated, frozen and lyophilized. The EAF was standardized as $17.82 \%$ $\mathrm{m} / \mathrm{m}$ (expressed in rutin) of total flavonoids by UV/VIS and $6.56 \% \mathrm{~m} / \mathrm{m}$ (expressed as myricitrin) by HPLC (Ramos et al., 2017).

\section{Selection of Microorganism}

In order to evaluate C. albicans resistance to phagocytosis by polimorphonuclears neutrophils, (PMNs), 48 clinical isolates obtained from renal transplant recipients with oral candidiasis (Project approved under 152/07 protocol) and both references strains, C. albicans ATCC90028 and C. albicans SC5314 were used. These strains were kept in the culture collection of the Medical and Molecular Mycology Laboratory, Department of Clinical and Toxicological Analyses, Federal University of Rio Grande do Norte.

For all the other experiments, we selected $C$. albicans strain 111R. We previously observed this is a highly filamentous strain after induction of morphogenesis in the presence of serum and other morphogenesis inducing media (Silva-Rocha et al., 2015).

The isolates were stored at $-80^{\circ} \mathrm{C}$ in YPD liquid medium (dextrose $20 \mathrm{~g} / \mathrm{L}$, peptone $20 \mathrm{~g} / \mathrm{L}$, yeast extract $10 \mathrm{~g} / \mathrm{L}$ ) containing $20 \%(\mathrm{v} / \mathrm{v})$ glycerol. The cryotubes of $2 \mathrm{~mL}$ of capacity (Cralplast; Cotia Sao Paulo, Brazil) were thawed on ice and $100 \mu \mathrm{L}$ of cells suspension of each strain were added to $5 \mathrm{~mL}$ of YPD liquid medium and incubated in a shaker afterwards (Tecnal, TE-420, São Paulo, Brazil), at $35^{\circ} \mathrm{C}$ for $48 \mathrm{~h}$ for the reactivation and verification of viability. Subsequently, $100 \mu \mathrm{L}$ of each cell suspension was inoculated on the surface of Sabouraud Dextrose Agar (SDA; Oxoid, UK) containing $300 \mu \mathrm{g} / \mathrm{mL}$ of chloramphenicol (Park-Davis), using a Drigalsky loop. The plates were incubated at $37^{\circ} \mathrm{C}$ for $48 \mathrm{~h}$. Yeast colonies were plated on CHROMagar ${ }^{\circledR}$ Candida (CHROMagar Microbiology, Paris,
France) to check for purity and screening for different color colonies. Species identification was based on the characteristics of the cells observed microscopically after cultivation on corn meal agar containing Tween 80, as well as classical methodology (Yarrow, 1998).

\section{NGY Broth to Standardize the Inoculum}

For all the virulence factors evaluated in vitro, all C. albicans strains (phagocytosis) and 111R only (further assays) were initially grown in NGY medium (Difco Neopeptone $1 \mathrm{~g} / \mathrm{L}$, Dextrose $4 \mathrm{~g} / \mathrm{L}$; Difco yeast extract $1 \mathrm{~g} / \mathrm{L}$ ) for $18-24 \mathrm{~h}$ in a rotatory shaker (Tecnal, TE-420, Sao Paulo, Brazil) at $30^{\circ} \mathrm{C}, 200 \mathrm{rpm}$. This culture medium produces an inoculums size of about $2 \times$ $10^{8}$ cells $/ \mathrm{mL}$. Cultures were spectrophotometrically measured at a wavelength of $600 \mathrm{~nm}$ ranging from 0.8 to 1.2 (Biochrom Libra S32). Subsequently, C. albicans cells were diluted to obtain the specific inoculum needed for each attribute of virulence evaluated in vitro (Chaves et al., 2007). For the experiments performed after growth in the presence of the EAF of E. uniflora, 1,000 $\mu \mathrm{g} / \mathrm{mL}$ of the natural product was added to the NGY broth. The experiments were performed in a manner that both control (in the absence of the EAF fraction) and test (in the presence of the EAF) assays had the same number of $C$. albicans viable cells after CFU counting, after $48 \mathrm{~h}$ of incubation in SDA.

\section{Candida albicans Killing by Polymorphonuclear Neutrophils}

PMNs freshly isolated from blood samples of the same healthy volunteer on the day of the experiment (Fradin et al., 2005) were suspended in Eagle's minimal essential medium (Gibco) + $20 \mathrm{mM}$ HEPES, $\mathrm{pH} 7.2$, and standardized to $8 \times 10^{5} \mathrm{PMN} / \mathrm{mL}$. C. albicans strain 111R cells grown overnight in NGY broth in the presence and absence of the EAF of E. uniflora were washed and resuspended to contain $5 \times 10^{6}$ yeasts $/ \mathrm{mL}$ in HEPES-buffered Eagle's minimal essential medium containing one-tenth volume of fresh human plasma for opsonization purposes. Equal volumes (100 $\mu \mathrm{l}$ ) of PMNs and yeast suspensions were mixed and incubated at $37^{\circ} \mathrm{C}$ for $3 \mathrm{~h}$ with rotation at 50 rpm (Tecnal, TE-420, Sao Paulo, Brazil). Phagocytosis of C. albicans was determined by counting the number of yeasts cells inside or attached to 100 PMNs with optical microscopy (CX21, Olympus, Japan; Chaves et al., 2012). The assay was performed in triplicate.

\section{Morphogenesis Assay in Candida albicans}

Morphogenesis was induced according to Chaves et al. (2007). C. albicans cells were grown overnight in NGY broth $\left(30^{\circ} \mathrm{C}-\right.$ $200 \mathrm{rpm}$ ) in the presence and absence of the EAF of E. uniflora. C. albicans cells were diluted in saline solution and standardized to $1 \times 10^{6}$ cells $/ \mathrm{ml}$.

In order to induce morphogenesis, C. albicans cells suspension was inoculated to $150 \mathrm{ml}$ of $20 \%(\mathrm{v} / \mathrm{v})$ Fetal Bovine Serum (FBS; Sigma-Aldrich; Missouri, Saint Louis, USA) in YPD broth in $200 \mathrm{ml}$ of capacity flasks. The strain was incubated under mechanical rotation at $37^{\circ} \mathrm{C}, 200 \mathrm{rpm}$, for a period of $3 \mathrm{~h}$ for further protein extraction. 


\section{Proteomics Analysis of Candida albicans Treated with the EAF of Eugenia uniflora}

A concentration of $1 \times 10^{6}$ cells/ml of $C$. albicans $111 \mathrm{R}$ cells was used. After morphogenesis induction, C. albicans cells were transferred to $15 \mathrm{~mL}$ conic tubes (Cralplast; Cotia Sao Paulo, Brazil), centrifuged for $20 \mathrm{~min}, 13,000 \mathrm{rpm}, 4^{\circ} \mathrm{C}$ (280R, FANEN) and washed three times with ice cold ultrapure water. Total protein extraction was performed with $C$. albicans cell pellets. Therefore, $5 \mathrm{ml}$ of Tris- $\mathrm{HCl} 10 \mathrm{mM}$ ( $\mathrm{pH} \mathrm{8.8)} \mathrm{buffer} \mathrm{containing} \mathrm{a}$ protease inhibitor solution cocktail (Protease Inhibitor Cocktail for use with mammalian cell and tissue extracts, DMSO solution, Sigma-Aldrich; Missouri, Saint Louis, USA) was added to the yeast cells (995 $\mu \mathrm{L}$ Buffer, $5 \mu \mathrm{L}$ of protease inhibitor) subsequently macerated with liquid nitrogen. The samples were centrifuged at $13,000 \mathrm{rpm}, 4^{\circ} \mathrm{C}$ and the supernatant was collected. The total protein concentration of the supernatant was quantified by Bradford method (Bradford, 1976) using Bovine Serum Albumin (BSA; Sigma-Aldrich; Missouri, Saint Louis, USA) as a standard and the absorbance readings were performed at 595 wavelength by spectrophotometer.

Protein profiles were analyzed with Sodium Dodecyl Sulfate Polyacrylamide Gel Electrophoresis, SDS-PAGE, under reducing conditions using the discontinuous buffer system (Laemmli, 1970; Studier, 1973).

Total soluble proteins were separated and analyzed by twodimensional electrophoresis (Görg et al., 2000). Firstly the proteins were submitted to Ettan IPGphor 3 (GE Healthcare) according to the following parameters: First gradient -500 $\mathrm{V}$, second gradient $-1,000 \mathrm{~V}$, third gradient $-8,000 \mathrm{~V}$, fourth gradient $-8,000 \mathrm{~V}, 20^{\circ} \mathrm{C}, 50 \mathrm{~mA}$. The second dimension was carried out for the separation of proteins according to molecular mass, and held on $12.5 \%(\mathrm{w} / \mathrm{v})$ polyacrylamide gel according to Laemmli (1970). Gels from tests and control experiments extracted proteins were stained with Coomassie Brilliant Blue G250, according to Neuhoff et al. (1988). The gels were scanned (Labscan, HuntersLab). The analysis of data was performed with the ImageMaster 2D Platinum 6.0 GE software.

The spots resulting from gel electrophoresis were then removed and cut into segments of $\sim 1 \mathrm{~mm}^{3}$. The fragments were subsequently destained with $400 \mu \mathrm{L}$ of decolorizing solution containing acetonitrile (ACN) 50\% (v/v) in ammonium bicarbonate $25 \mathrm{mM}$, stirred with a vortex for 10 min between each washing until the complete removal of the dye. Gel excised fragments were then completely dehydrated with $200 \mu \mathrm{L}$ of $100 \% \mathrm{ACN}$ and than dried in a concentrator (Vacfuge Plus ${ }^{\mathrm{TM}}$, Eppendorf). The fragments were subsequently rehydrated with $40 \mu \mathrm{L}$ of Dithiothreitol $(20 \mathrm{mM}$ DTT in $50 \mathrm{mM}$ ammonium bicarbonate) for $40 \mathrm{~min}$ at $56^{\circ} \mathrm{C}$. After rehydration was carried out, alkylation with $40 \mu \mathrm{L}$ of iodoacetamide solution (55 mM iodoacetamide in $50 \mathrm{mM}$ ammonium bicarbonate) was performed. A second dehydration was performed with $200 \mu \mathrm{L}$ of ACN (100\%). Subsequently, $15 \mu \mathrm{L}$ of trypsin solution in acetic acid $(100 \mathrm{ng} / \mu \mathrm{L})$ was added to the dried gel fragments which were then rehydrated in ice. A $40 \mu \mathrm{L}$ volume of $25 \mathrm{mM}$ ammonium bicarbonate was added and the fragments were incubated at $37^{\circ} \mathrm{C}$ for $14 \mathrm{~h}$. The reaction was stopped with $15 \mu \mathrm{L}$ of blocking solution
(ACN 50\% (v/v) and formic acid 5\% (v/v). Three elutions were carried (repated twice each time) and supernatants were collected after all elutions. The first elution was performed with $40 \mu \mathrm{L}$ of methanol $60 \%(\mathrm{v} / \mathrm{v})$ and formic acid $1 \%(\mathrm{v} / \mathrm{v})$, and then the samples sonicated for $15 \mathrm{~min}$ at $40^{\circ} \mathrm{C}$. For the second elution $40 \mu \mathrm{L}$ of ACN $50 \%(\mathrm{v} / \mathrm{v})$ and formic acid $1 \%(\mathrm{v} / \mathrm{v})$ was added and then samples were sonicated for $15 \mathrm{~min}$ at $40^{\circ} \mathrm{C}$. A volume of $40 \mu \mathrm{L}$ of ACN $100 \%$ was added to dehydrate gel fragments, subsequently sonicated for $15 \mathrm{~min}$. The eluted peptides were then subjected to concentration in a Concentrator (Vacfuge Plus $^{\mathrm{TM}}$, Eppendorf) during $30 \mathrm{~min}$. After concentration, samples were resuspended in $10 \mu \mathrm{L}$ of trifluoroacetic acid (TFA) $0.1 \%$ $(\mathrm{v} / \mathrm{v})$ in $100 \% \mathrm{ACN}$ and subjected to purification before mass spectrometry analysis.

Purification was performed using Reverse Phase-Pippete Zip-Tip (Millipore) following the manufacturer's instructions. Peptide samples were resuspended in $0.1 \%(\mathrm{w} / \mathrm{v})$ TFA solution. The ZipTips were equilibrated with $10 \mu \mathrm{L}$ of a solution containing ACN and $0.1 \%$ TFA and the solution discarded afterwards. This procedure was performed three times. A $10 \mu \mathrm{L}$ volume of water and $0.1 \%$ TFA solution was gently homogenized and further discharged for three times. To bind the samples inside the pipette tips to columns, $10 \mu \mathrm{L}$ of sample peptides were aspirated for 7 to 10 times to increase fixation to columns. After binding of the peptides to columns, two washing steps were performed. Firstly, $10 \mu \mathrm{L}$ of a $5 \%(\mathrm{v} / \mathrm{v})$ methanol and $0.1 \%$ TFA solution was added and the process repeated three times. The elution process was ended after gentle homogenization of peptides the addition of $5 \mu \mathrm{L}$ of $0.1 \%$ TFA solution in $50 \% \mathrm{ACN}$ and subsequently the samples were transferred to clean $2 \mathrm{~mL}$ microcentrifuge tubes (Salvato and Carvalho, 2010).

After trypsin digestion and purification, the peptides were then analyzed by mass spectrometry. The peptides were identified by mass spectrometry by MALDI-TOF/TOF equipment (TOF/TOF ${ }^{\mathrm{TM}} 5800$ System, Sciex), the fragmentation spectra (MS/MS) containing the molecular weights of the peptides were evaluated using the MASCOT database (MatrixScience). Morphogenesis assays and proteomic analysis were perdormed in triplicate.

\section{Murine Model of Oral Candidiasis}

The evaluation of the effect of the EAF of E. uniflora on filamentation of $C$. albicans was performed in vivo according to Solis and Filler (2012). Twenty-four adult mice (Mus musculus) of 12 weeks old weighing $18-25 \mathrm{~g}$ were used. The animals were obtained from the Animal House of the Center of Health Sciences, Federal University of Rio Grande do Norte, kindly provided by Dr. Antonia Cláudia Jácome da Câmara. Water and food were provided ad libitum throughout the study period. The day before animal's experimentation, C. albicans $111 \mathrm{R}$ was grown overnigth in NGY broth in the absence (control experiment) and presence (test experiment) of $1,000 \mu \mathrm{g} / \mathrm{mL}$ of the EAF of E. uniflora at $30^{\circ} \mathrm{C}, 200 \mathrm{rpm}$ for $18-24 \mathrm{~h}$. The animals were weighed a day before inoculation to calculate the dose of the immunosuppressant (prednisolone, EMS; Hortolandia, Sao Paulo, Brazil) subcutaneously administered to each individual $(100 \mathrm{mg} / \mathrm{kg}$ in $200 \mu \mathrm{L})$. Prednisolone was administered a 
day previously to infection and 3 days after infection. An inoculum of $1 \times 10^{6}$ cells of $C$. albicans $111 \mathrm{R}$ strain was prepared in PBS buffer. The animals were intraperitoneally anesthetized with a mixture of ketamine (Francotar ${ }^{\circledR}$, Virbac;110 $\mathrm{mg} / \mathrm{kg}$ ) and xylazine (Calmiun ${ }^{\circledR}$, Agener União) $(10 \mathrm{mg} / \mathrm{kg})$. After anesthetizing the animals, a sterile swab was inserted in microcentrifuge tubes containg C. albicans inoculum, all the cells suspension $(100 \mu \mathrm{L})$ was dropped and rubbed on the oral cavity of the animals during $60 \mathrm{~s}$. CFU counts were performed before inoculation to verify if cells were viable.

The animals were divided in three different groups: Group I: Animals that were infected with C. albicans strain 111R grown in NGY broth the absence of E. uniflora EAF. Group II: Animals that were infected with $C$. albicans strain $111 \mathrm{R}$ grown in NGY broth in the presence of E. uniflora EAF and Group III: Animals that were infected with $C$. albicans strain $111 \mathrm{R}$ grown in NGY broth in the absence of E. uniflora EAF, where the fraction was administered to the animals tongue after infection.

The animals from group III were intraperitoneally anesthetized with a mixture of ketamine $(110 \mathrm{mg} / \mathrm{kg})$ and xylazine $(10 \mathrm{mg} / \mathrm{kg}) 2$ days after the infection was established, and were subsequently treated by admiministring $50 \mu \mathrm{L}$ of the E. uniflora $\operatorname{EAF}(1,000 \mu \mathrm{g} / \mathrm{mL})$ onto the dorsum of the tongue for 3 times in intervals of $10 \mathrm{~min}$.

The animals were sacrificed 5 days after infection with excessive dose of ketamine $(110 \mathrm{mg} / \mathrm{kg})$ and xylazine $(10 \mathrm{mg} / \mathrm{kg})$. A sterile swab was rubbed on the oral cavity of animals and introduced into a microcentrifuge tube containing $1 \mathrm{ml}$ of $0.9 \%$ $(\mathrm{w} / \mathrm{v})$ saline. The samples were diluted 1:10 and seeded on the surface of $90 \times 120 \mathrm{~mm}$ Petri dishes containing Sabouraud dextrose agar with $300 \mu \mathrm{g} / \mathrm{mL}$ chloramphenicol and incubated at $37^{\circ} \mathrm{C}$ for $48 \mathrm{~h}$ to perform $\mathrm{CFU}$ counting.

The animals tongues were excised with the aid of a sterile scalpel and immediately fixed in formaldehyde $10 \%(\mathrm{v} / \mathrm{v})$ in PBS for further histopathological analysis of the tissue. After fixation steps, the samples were dehydrated with graded ethanol and diaphanized xylene. The samples were embedded in paraffin and sliced in eight $\mathrm{mm}$ of thickness, for the manufacture of the slides and then stained with hematoxylin-eosin for subsequent evaluation step of the cellular infiltrate and PAS (Periodic Acid Schiff) to assess the fungal load in a light microscope. In order to evaluate tissue damage resulting from the infection, the formation of tissue ulcers, erosion process, inflammatory response, as well as the type of response and presence and fungal burden at the infection site were evaluated.

\section{Cell Viability Assay}

Cell viability was studied in A549 cell lines at a concentration of $2.5 \times 10^{2}$ cells per well. E. uniflora ethyl acetate fraction was tested in concentrations of 8,000,4,000, 2,000, 1,000, 500, $250,125,62.5,37$, and $18 \mu \mathrm{g} / \mathrm{mL}$. Cytotoxicity was assessed by the MTT assay (bromide (3- [4,5-dimethyl-thiazol-2-yl] -2,5diphenyltetrazolium bromide) (Sigma-Aldrich; Missouri, Saint Louis, USA), used at a concentration of $5 \mathrm{mg} / \mathrm{ml}$ according with Mosmann (1983) with some modifications.

The starting solution with the EAF fraction of E. uniflora was subsequently serially diluted in the specific medium used for cell line in the previously prepared microplates containing the mammalian cells. The plates were incubated at $37^{\circ} \mathrm{C}, 5 \%$ $\mathrm{CO}_{2}$ under light for $24 \mathrm{~h}$. The solution containing the fraction was removed and $10 \mu \mathrm{L}$ of MTT solution was added to the wells, following another incubation step at $37^{\circ} \mathrm{C}$ for a period of $4 \mathrm{~h}$, as previously described (Denizot and Lang, 1986; Gerlier and Thomasset, 1986; Ferrari et al., 1990). After the incubation time, the MTT solution was removed and added to $100 \mu \mathrm{L}$ of isopropanol for diluting the precipitate. Viable cells changed their color from yellow to violet. Untreated cells constituted the positive control (viable cells), and cells treated with hydrogen peroxide (Sigma-Aldrich, St. Louis, MO, USA) constituted the negative control (dead cells). The spectrophotometric reading of the plates was performed in the microplate ELISA reader (BioRad model 3550) with a wavelength of $570 \mathrm{~nm}$. The percentage of viable cells was calculated as follows:

Viable cells $\%=$ average test X100/average of negative control

\section{RESULTS}

\section{Candida albicans Killing by Polymorphonuclear Neutrophils}

In a previous study performed by our group, we realized that the extract of E. uniflora was able to impair proper hypha formation in both solid and liquid media (YPD+20\% serum, Spider and $\mathrm{N}$-acetyl-D-glucosamine; Silva-Rocha et al., 2015). In addition, the typical oval morphological form of C. albicans blastoconidia was altered; showing invaginations of the cell wall and an increase in the size of citoplasmic vacuoles. We hypothesized that the extract was somehow acting on the cell wall, and then we investigated how C. albicans cells grown in the presence of E. uniflora would interact with phagocytic cells. Therefore, we performed phagocytosis assays with PMNs.

PMNs were co-incubated with $C$. albicans cells that were previously grown overnight in the presence and absence of the EAF of E. uniflora. In the absence of the ethyl acetate fraction, C. albicans strains had a broad variability of number of yeasts phagocytized by $100 \mathrm{PMNs}$, ranging from $11 \pm 3.2$ (Strain 111R) to $176 \pm 11.6$ and $176 \pm 6.1$ (Strains 44 and $10 \mathrm{Li}$, respectively) yeasts/100 PMNs. The mean value of the number of $C$. albicans phagocytized by 100 PMNs for all the strains was $120.36 \pm 36.71$ yeasts/100 PMNs (Table 1).

When $C$. albicans cells were grown overnight in the presence of E. uniflora extract, a significant reduction in the number of cells phagocytized by the PMNs was observed (Figure 1B). The number of C. albicans phagocytized by 100 PMNs ranged from 10 \pm 1 to $10 \pm 5.5$ yeasts/100 PMNs (Strain 18A and 111R) to $91 \pm$ 9.1 yeasts/100 PMNs (Strain 46; Table 1). A comparison among the mean value of phagocytosis of the control group (absence of the EAF) with the test group shows a significant reduction in the number of cells phagocytized by PMNs (120.36 \pm 36.71 vs. $44.68 \pm 19.84$ yeasts/100 PMNs; Table 1). Phagocytosis of C. albicans cells by PMNs and hypha formation may be observed when cells were cultivated in the absence of the EAF of E. uniflora (Figure 1A). 
TABLE 1 | Phagocytosis by polymorphonuclear neutrophils of Candida albicans clinical isolates obtained from the oral cavity of kidney transplant recipients after $3 \mathrm{~h}$ of incubation in Eagle's minimal essential medium buffered with HEPES, pH 7.2 media at $37^{\circ} \mathrm{C}, 200 \mathrm{rpm}$.

\begin{tabular}{|c|c|c|c|}
\hline Strain & $\begin{array}{l}\text { No of C. albicans cells } \\
\text { phagocitized by } 100 \\
\text { PMNs* }\end{array}$ & Strain & $\begin{array}{l}\text { No of C. albicans cells } \\
\text { phagocitized by } 100 \\
\text { PMNs* }^{\star}\end{array}$ \\
\hline 0028 & 5 vs. $17 \pm 6.5^{\dagger}$ & Strai & $176 \pm 11.6$ vs. $63 \pm 7.5^{\dagger}$ \\
\hline SC5314 & $137 \pm 20.6$ vs. $16 \pm 3.5^{\dagger}$ & Strain46 & $172 \pm 20.1$ vs. $91 \pm 9.1^{\dagger}$ \\
\hline Strain01 & $134 \pm 15.3$ vs. $26 \pm 1.2^{\dagger}$ & Strain50 & $157 \pm 36.6$ vs. $52 \pm 10^{\dagger}$ \\
\hline Strain02 & $115 \pm 14.6$ vs. $14 \pm 3.2^{\dagger}$ & Strain51 & $130 \pm 19.5$ vs. $74 \pm 13.7^{\dagger}$ \\
\hline Strain03 & $66 \pm 7.9$ vs. $20 \pm 0.6^{\dagger}$ & Strain53 & $132 \pm 15.9$ vs. $49 \pm 10.3^{\dagger}$ \\
\hline Strain05 & $98 \pm 6.7$ vs. $48 \pm 8.2^{\dagger}$ & Strain54 & $132 \pm 9.2$ vs. $46 \pm 11.1^{\dagger}$ \\
\hline Strain06 & $100 \pm 12.5$ vs. $23 \pm 6.5^{\dagger}$ & Strain60 & $146 \pm 9$ vs. $57 \pm 11.6^{\dagger}$ \\
\hline Strain08 & $130 \pm 19$ vs. $50 \pm 9^{\dagger}$ & Strain61 & $142 \pm 9.2$ vs. $56 \pm 11.1^{\dagger}$ \\
\hline Strain10 & vs. $35 \pm 12.5^{\dagger}$ & Strain70 & $140 \pm 12.7$ vs. $61 \pm 9.9^{\dagger}$ \\
\hline Strain11 & $28 \pm 3.5$ vs. $14 \pm 2.5$ & Strain72 & $136 \pm 9$ vs. $67 \pm 11.6^{\dagger}$ \\
\hline Strain12 & $150 \pm 11.1$ vs. $81 \pm 15.4^{\dagger}$ & Strain82 & $130 \pm 13.2$ vs. $51 \pm 9.9^{\dagger}$ \\
\hline Strain13 & $126 \pm 31.6$ vs. $42 \pm 4^{\dagger}$ & Strain85 & $144 \pm 9.5$ vs. $53 \pm 6.1^{\dagger}$ \\
\hline Stra & $98 \pm 20.2$ vs. $70 \pm 4^{\dagger}$ & 07 & $156 \pm 10.1$ vs. $71 \pm 9.9^{\dagger}$ \\
\hline Stra & $86 \pm 21.2$ vs. $39 \pm 17.2^{\dagger}$ & Stra & $80 \pm 17.4$ vs. $37 \pm 6.1^{\dagger}$ \\
\hline Strain21 & $114 \pm 21.5$ vs. $37 \pm 10.6^{\dagger}$ & Strain06L & $75 \pm 8.7$ vs. $24 \pm 1^{\dagger}$ \\
\hline Strain23 & $101 \pm 11.4$ vs. $62 \pm 4.6^{\dagger}$ & Strain10Li & $176 \pm 6.1$ vs. $34 \pm 2^{\dagger}$ \\
\hline Strain24 & $132 \pm 13.9$ vs. $57 \pm 8.5^{\dagger}$ & Stra & $105 \pm 14.7$ vs. $41 \pm 14$. \\
\hline Strain28 & $165 \pm 9.5$ vs. $76 \pm 13.4^{\dagger}$ & Strain12A & $59 \pm 16.8$ vs. $15 \pm 4.2^{\dagger}$ \\
\hline Strain30 & $119 \pm 20$ vs. $44 \pm 17.6^{\dagger}$ & Strain12L & $90 \pm 13.2$ vs. $28 \pm 3.5^{\dagger}$ \\
\hline Strain31 & $129 \pm 15$ vs. $56 \pm 14.5^{\dagger}$ & $15 \mathrm{~A}$ & $116 \pm 27.1$ vs. $39 \pm 7^{\dagger}$ \\
\hline Strain32 & $123 \pm 13.2$ vs. $60 \pm 6.1^{\dagger}$ & Strain15G & $86 \pm 21.9$ vs. $34 \pm 3.1^{\dagger}$ \\
\hline Strain34 & $156 \pm 16.5$ vs. $67 \pm 8.2^{\dagger}$ & Strain15L & $76 \pm 16.5$ vs. $38 \pm 4^{\dagger}$ \\
\hline Strain37 & $124 \pm 19.1$ vs. $41 \pm 17.6^{\dagger}$ & Strain18A & $102 \pm 11.2$ vs. $10 \pm 1^{\dagger}$ \\
\hline Strain40 & $142 \pm 15.9$ vs. $59 \pm 10.3^{\dagger}$ & Strain111L & $80 \pm 17.4$ vs. $37 \pm 6.1^{\dagger}$ \\
\hline Strain41 & $172 \pm 21$ & Strain111R & /s. $10 \pm 5.5$ \\
\hline
\end{tabular}

*Presence vs. Absence of EAFof Eugenia uniflora extract.

${ }^{\dagger}$ Statistically significant $P<0.05$.

Surprisingly, when C. albicans cells were grown overnight in the presence of the E. uniflora EAF, a significant reduction in the number of cells phagocytized by the PMNs was observed (Figure 1B). The number of C. albicans phagocytized by 100 PMNs ranged from $10 \pm 1$ to $10 \pm 5.5$ yeasts/100 PMNs (Strain $18 \mathrm{~A}$ and $111 \mathrm{R}$ ) to $91 \pm 9.1$ yeasts/100 PMNs (Strain 46; Table 1). A comparison among the mean value of phagocytosis of the control group (absence of the fraction) with the test group shows a significant reduction in the number of cells phagocytized by PMNs (120.36 \pm 36.71 vs. $44.68 \pm 19.84$ yeasts/100 PMNs; Table 1).

It is important to emphasize again that C. albicans $111 \mathrm{R}$ is a highly filamentous strain found in our previous publication (Silva-Rocha et al., 2015). Due to its highly filamentous phenotype, which can be easily observed even when this strain is not incubated in hypha inducing conditions; this strain was not promptly phagocytized. Therefore, we could not observe a significant reduction in the number of phagocytized cells when this strain was previously grown in the presence of the EAF, because this strain was already poorly phagocytized $(P>0.05)$.
However, because this was the most filamentous strain found in our study and we would like to prove that this natural product was able to impair morphogenesis, we chose it to perform our proteomic assays.

\section{Global Analysis of Candida albicans Proteomics in Morphogenesis Induced with Fetal Bovine Serum}

Because we observed that C. albicans $111 \mathrm{R}$ was the most filamentous strain, but also showed reduced ability to form filaments in the presence of inducing media after growth in the presence of the EAF, we selected this strain to analyze which proteins are differentially expressed in the of the referred fraction. The induction of filamentation was performed in $\mathrm{YPD}+20 \%$ serum at $37^{\circ} \mathrm{C}$, for $3 \mathrm{~h}$ and proteins were analyzed by bidimensional electrophoresis. A total of 39 proteins, conserved in the three different 2D-gels (triplicate assays), were selected and then identified by MALDI-TOF mass spectrometry. Proteins identification and their biological functions are described in Table 2.

The proteins identified were classified within seven distinct categories based on their biological function, as follows: Energy (Pam16, Atp2, Rcf1, Caglog03245g, Cox4, Ndk1, and Cawg_02398), Protein Metabolism (Gtp1, Cyp9, Rpl3, Pca2, Mrpl4, Rpn6, Dbp10, Tef1, and Mrh4), Glucose Metabolism (Eno1, Fba1, and Med7), Transport (Yet2, Sec1, Acb2, and Mth1), Nucleic Acid Metabolism (Tpp1, Rex3, and Lsm3), Cell Structure (Gim4, Atg26, and End3) and Stress Response (Ssb1). Three proteins (Mcpb, Ynr1, and Spg4) were not included in any of the categories, while two of them (Irc10 and Spac24c9.04) had unknown functions (Table 3).

From the total 39 proteins identified and classified, $23.1 \%$ were included in the "Protein Metabolism" category, generally associated with protein synthesis and structural formation of ribosomes. A total of $17.9 \%$ of identified proteins were included in the "Energy" category, and mitochondrial biogenesis and ATP synthesis were the main functions observed. The three proteins classified in "Glucose metabolism" group were related to glycolytic pathways. All proteins categorized in the "Transport" group were correlated with the maintenance of cell functions by promoting the transport of glucose and protein in the cytoplasm of C. albicans cells.

Proteins involved in the "Nucleic Acid Metabolism" were associated with biological functions of DNA repairing, RNA processing and protein folding. Membrane synthesis and endocytosis are functions related to the "Cell structure" group. Only a single protein (Ssb1) was included in the "Stress Response" group and its biological function is related to protein biosynthesis and stress response.

\section{Proteomics Analysis of Candida albicans Treated with the EAf of Eugenia uniflora}

The pattern of C. albicans differentially expressed proteins in the presence of the EAF of E. uniflora is described in Table 4. Eight proteins were overexpressed in the presence of the EAF (Pam16, Med7, Atp2, Rcf1, Eno1, Ynr1, Spg4, and Ssb1), while 10 proteins 




FIGURE 1 | Phagocytosis of Candida albicans SC5314 cells by polymorphonuclear neutrophils after $3 \mathrm{~h}$ of incubation in Eagle's minimal essential medium buffered with HEPES, pH 7.2 media at $37^{\circ} \mathrm{C}, 200 \mathrm{rpm}$. (A) C. albicans cells grown overnight in NGY broth at $30^{\circ} \mathrm{C}$, in the absence of $E$. uniflora extract (Black arrow: C. albicans inside PMNs. White arrow: Blastoconidia non-phagocytized). (B) C. albicans cells grown overnight in NGY broth containing $E$. uniflora EAF (1,000 $\mu \mathrm{g} / \mathrm{mL})$. Black arrow: PMN; White arrow, C. albicans blastoconidia.

showed reduced expression, as follows: Gtp1, Nuf2, Cyp9, Acb2, Mug97, Cox4, Yet2, Mth1, Ndk1, and Gim4.

Several biological processes were affected when the EAF of E. uniflora was added to C. albicans 111R NGY broth and morphogenesis was further induced. Proteins involved in generation of energy by ATP synthesis (Atp2), mitochondrial biogenesis (Pam16 and Rcf1) and glycolytic pathway (Med7 and Eno1) were overexpressed in the presence of the fraction. Heat Shock Protein Ssb1, involved in C. albicans stress response was also overexpressed in the presence of the EAF (Table 4).

Proteins involved in the structural organization of C. albicans were down regulated during morphogenesis after growth in the presence of the EAF. Cytoplasmic transport of proteins (Acb2) and cell division process (Nuf2 and Mug97) also showed decreased protein expression in the presence of the EAF of $E$. uniflora. Protein synthesis (Gtp1 and Cyp9) and folding (Gim4) were also negatively induced in the presence of the fraction (Table 4).

\section{Murine Model of Oral Candidiasis}

The effect of the EAF of E. uniflora in C. albicans hypha formation and pathogenicity was evaluated in vivo under three different conditions: Group I: C. albicans strain 111R grown in NGY broth the absence of the E. uniflora EAF. Group II C. albicans strain $111 \mathrm{R}$ grown in NGY broth the presence of $E$. uniflora EAF and Group III: C. albicans strain 111R grown in NGY broth in the absence of E. uniflora EAF, where the natural product was administered to the animal's tongue after infection.

In the macroscopic analysis of the tongue dorsum of mice infected with C. albicans grown in the absence of the E. uniflora EAF, the presence of lesions with pseudomembranous white plaques corresponding to establishment of oral candidiasis was observed (Groups I and III; Figure 2A) while the group of mice infected in the oral cavity with $111 \mathrm{R}$ strain grown overnight in the presence of the EAF of E. uniflora was macroscopically less affected with the infection and pseudomembranous white plaque in the dorsum of tongue was not observed (Group II;
Figure 2B). Two days after the infection, the animals from group III were treated by administering the fraction on the surface of the tongue, reducing the progression of the formation of white pseudomembranous confluent plaques when compared with group I, which did not received treatment.

A sterile swab was rubbed in the oral cavity of animals and introduced into a tube containing $1 \mathrm{ml}$ of $0.9 \%$ saline to perform direct examination and culture on SDA to analyze the fungal burden by $\mathrm{CFU} / \mathrm{ml}$ counts. In the microscopical analysis of the sample collected from the mice belonging to Group I, we observed the presence of cellular clumps of long hyaline and septate hyphae (Figure 3A). The direct examination of samples obtained from mice belonging to Groups II and III showed visually shortest pseudo-hyphae and true-hyphae (Figure 3B). This difference was more pronounced for Group II samples.

Oral cavity samples were seeded on the surface of SDA, incubated at $37^{\circ} \mathrm{C}$ to perform $\mathrm{CFU}$ counting. The number of $\mathrm{CFU} / \mathrm{mL}$ is described in the Figure 4. A reduction in the number of CFU from $2.36 \log _{10} \mathrm{CFU} / \mathrm{ml}$ to $1.85 \log _{10}$ (Groups I and II, respectively) and from $2.36 \log _{10} \mathrm{CFU} / \mathrm{ml}$ to $1.92 \log _{10}$ (Groups I and III, respectively) was observed. The histopathological analysis of the mice tongue infected with C. albicans was performed. The mucosa damage and fungal presence were evaluated with HE and PAS staining. The presence and absence of ulceration, erosion, inflammatory response and type of inflammatory cells were analyzed (Figures $\mathbf{5 A}-\mathbf{H}$ ). The animals belonging to Group I showed both more extensive tissue damage and fungal presence, specifically filamentous forms (long pseudo-hyphae and true hyphae), while the animals belonging to Groups II and III had less tissue damage and fungal presence (Figures 5A-H).

\section{Cell Viability Assay}

To ensure the safety and evaluate the cytotoxic effect of the EAFof E. uniflora in human cells, a MTT assay was performed using A549 cells, in concentrations ranging from 8,000 to 18 $\mu \mathrm{g} / \mathrm{mL}$. The extract was not toxic against the cells tested, which 
TABLE 2 | Effect of EAF of Eugenia uniflora (1,000 $\mu \mathrm{g} / \mathrm{mL})$ on global protein profile of Candida albicans 111R strain after morphogenesis induction in fetal bovine serum after $3 \mathrm{~h}$ of incubation at $37^{\circ} \mathrm{C}, 200 \mathrm{rpm}$.

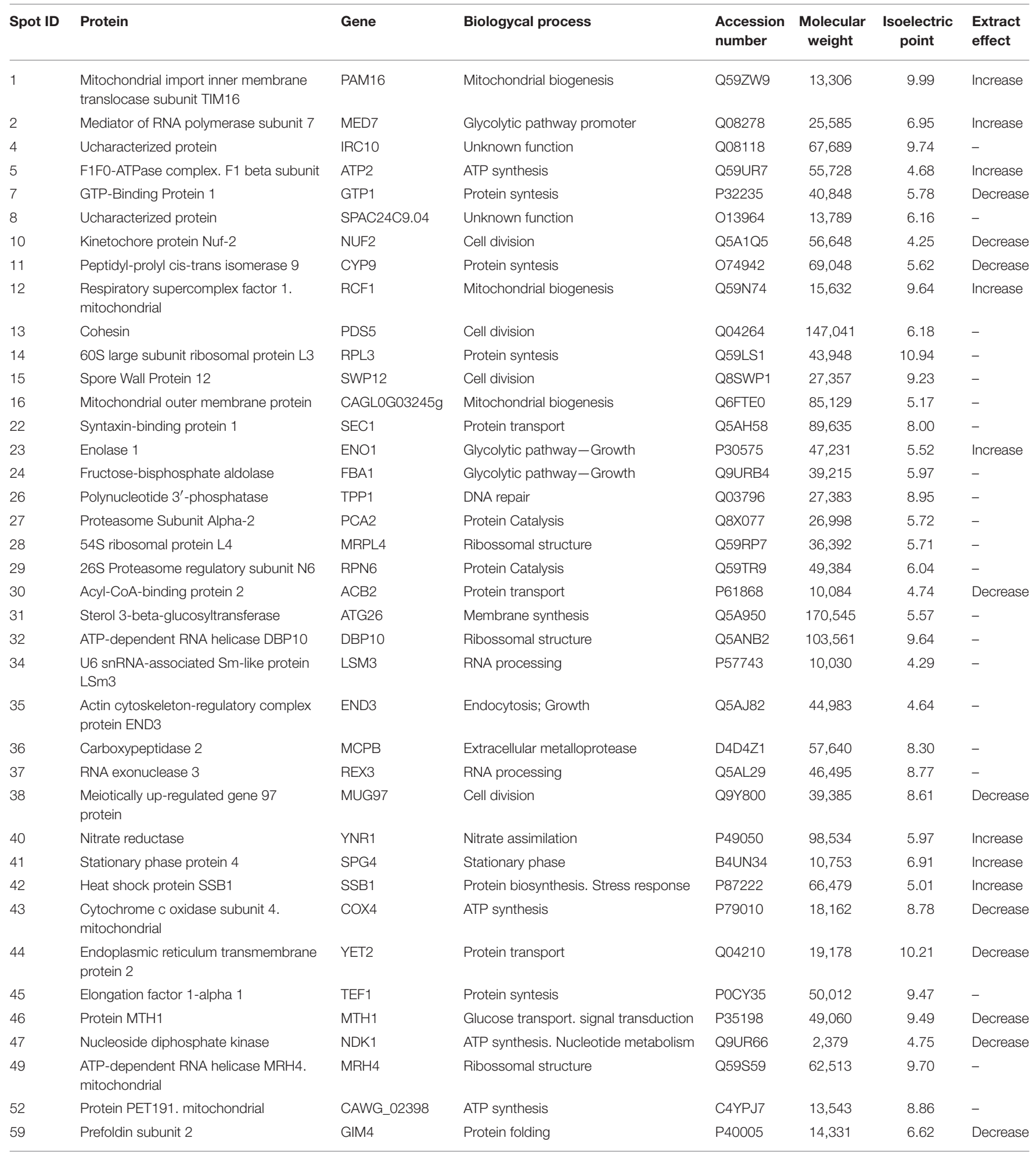

showed high viability over than $80 \%$ of cells even when the fraction concentration was 8-folds higher than the concentration used to perform all the experiments of the present study (Figure 6).

\section{DISCUSSION}

In order to investigate the effect of the Eugenia uniflora EAF in protein profile of $C$. albicans and in a murine model of 
TABLE 3 | Categorization of proteins identified in Candida albicans 111R strain treated with EAF of Eugenia uniflora $(1,000 \mu \mathrm{g} / \mathrm{mL})$ after morphogenesis induction in fetal bovine serum after $3 \mathrm{~h}$ of incubation at $37^{\circ} \mathrm{C}, 200 \mathrm{rpm}$.

\begin{tabular}{|c|c|c|}
\hline Group of proteins & Gene & Biological process \\
\hline \multicolumn{3}{|l|}{ ENERGY } \\
\hline $\begin{array}{l}\text { Mitochondrial import inner membrane } \\
\text { translocase subunit TIM16 }\end{array}$ & PAM16 & $\begin{array}{l}\text { Mitochondrial } \\
\text { biogenesis }\end{array}$ \\
\hline F1F0-ATPase complex. F1 beta subunit & ATP2 & ATP synthesis \\
\hline $\begin{array}{l}\text { Respiratory supercomplex factor } 1 . \\
\text { mitochondrial }\end{array}$ & RCF1 & $\begin{array}{l}\text { Mitochondrial } \\
\text { biogenesis }\end{array}$ \\
\hline Mitochondrial outer membrane protein & CAGL0G03245g & $\begin{array}{l}\text { Mitochondrial } \\
\text { biogenesis }\end{array}$ \\
\hline $\begin{array}{l}\text { Cytochrome c oxidase subunit } 4 . \\
\text { mitochondrial }\end{array}$ & cox4 & ATP synthesis \\
\hline Nucleoside diphosphate kinase & NDK1 & $\begin{array}{l}\text { ATP synthesis. } \\
\text { Nucleotide } \\
\text { metabolism }\end{array}$ \\
\hline Protein PET191. mitochondrial & CAWG_02398 & ATP synthesis \\
\hline \multicolumn{3}{|l|}{ PROTEIN METABOLISM } \\
\hline GTP-Binding Protein 1 & GTP1 & Protein syntesis \\
\hline Peptidyl-prolyl cis-trans isomerase 9 & CYP9 & Protein syntesis \\
\hline $60 S$ large subunit ribosomal protein L3 & RPL3 & Protein syntesis \\
\hline Proteasome Subunit Alpha-2 & PCA2 & Protein Catalysis \\
\hline 54 S ribosomal protein L4 & MRPL4 & Ribossomal structure \\
\hline 26S Proteasome regulatory subunit N6 & RPN6 & Protein Catalysis \\
\hline ATP-dependent RNA helicase DBP10 & DBP10 & Ribossomal structure \\
\hline Elongation factor 1 -alpha 1 & TEF1 & Protein syntesis \\
\hline $\begin{array}{l}\text { ATP-dependent RNA helicase MRH4. } \\
\text { mitochondrial }\end{array}$ & $\mathrm{MRH} 4$ & Ribossomal structure \\
\hline \multicolumn{3}{|l|}{ GLUCOSE METABOLISM } \\
\hline Enolase 1 & ENO1 & $\begin{array}{l}\text { Glycolytic } \\
\text { pathway-Growth }\end{array}$ \\
\hline Fructose-bisphosphate aldolase & FBA1 & $\begin{array}{l}\text { Glycolytic } \\
\text { pathway-Growth }\end{array}$ \\
\hline Mediator of RNA polymerase subunit 7 & MED7 & $\begin{array}{l}\text { Glycolytic pathway } \\
\text { promoter }\end{array}$ \\
\hline \multicolumn{3}{|l|}{ CELL DIVSION } \\
\hline Kinetochore protein Nuf-2 & NUF2 & Cell division \\
\hline Cohesin & PDS5 & Cell division \\
\hline Spore Wall Protein 12 & SWP12 & Cell division \\
\hline Meiotically up-regulated gene 97 protein & MUG97 & Cell division \\
\hline \multicolumn{3}{|l|}{ TRANSPORT } \\
\hline $\begin{array}{l}\text { Endoplasmic reticulum transmembrane } \\
\text { protein } 2\end{array}$ & YET2 & Protein transport \\
\hline Syntaxin-binding protein 1 & SEC1 & Protein transport \\
\hline Acyl-CoA-binding protein 2 & ACB2 & Protein transport \\
\hline Protein MTH1 & MTH1 & $\begin{array}{l}\text { Glucose transport. } \\
\text { signal transduction }\end{array}$ \\
\hline \multicolumn{3}{|l|}{ NUCLEI ACID METABOLISM } \\
\hline Polynucleotide $3^{\prime}$-phosphatase & TPP1 & DNA repair \\
\hline RNA exonuclease 3 & REX3 & RNA processing \\
\hline $\begin{array}{l}\text { U6 snRNA-associated Sm-like protein } \\
\text { LSm3 }\end{array}$ & LSM3 & RNA processing \\
\hline \multicolumn{3}{|l|}{ CELL STRUCTURE } \\
\hline Prefoldin subunit 2 & GIM4 & Protein folding \\
\hline
\end{tabular}

(Continued)
TABLE 3 | Continued

\begin{tabular}{|c|c|c|}
\hline Group of proteins & Gene & Biological process \\
\hline Sterol 3-beta-glucosyltransferase & ATG26 & Membrane synthesis \\
\hline $\begin{array}{l}\text { Actin cytoskeleton-regulatory complex } \\
\text { protein END3 }\end{array}$ & END3 & Endocytosis; Growth \\
\hline \multicolumn{3}{|l|}{ STRESS RESPONSE } \\
\hline Heat shock protein SSB1 & SSB1 & $\begin{array}{l}\text { Protein biosynthesis. } \\
\text { Stress response }\end{array}$ \\
\hline \multicolumn{3}{|l|}{ OTHER FUNCTION } \\
\hline Carboxypeptidase 2 & MCPB & $\begin{array}{l}\text { Extracellular } \\
\text { metalloprotease }\end{array}$ \\
\hline Nitrate reductase & YNR1 & Nitrate assimilation \\
\hline Stationary phase protein 4 & SPG4 & Stationary phase \\
\hline \multicolumn{3}{|l|}{ UNKNOWN FUNCTION } \\
\hline Ucharacterized protein & $\mathrm{IRC} 10$ & Unknown function \\
\hline Ucharacterized protein & SPAC24C9.04 & Unknown function \\
\hline
\end{tabular}

TABLE 4 | Proteins differentially expressed and corresponding biological process of Candida albicans 111R strain treated with EAF of Eugenia uniflora (1,000 $\mu \mathrm{g} / \mathrm{mL}$ ) after morphogenesis induction in fetal bovine serum after $3 \mathrm{~h}$ of incubation at $37^{\circ} \mathrm{C}, 200 \mathrm{rpm}$

\begin{tabular}{|c|c|c|}
\hline Proteins & Gene & Biological process \\
\hline \multicolumn{3}{|l|}{ INCREASE } \\
\hline $\begin{array}{l}\text { Mitochondrial import inner membrane } \\
\text { translocase subunit TIM16 }\end{array}$ & PAM16 & Mitochondrial biogenesis \\
\hline Mediator of RNA polymerase subunit 7 & MED7 & $\begin{array}{l}\text { Glycolytic pathway } \\
\text { promoter }\end{array}$ \\
\hline F1F0-ATPase complex. F1 beta subunit & ATP2 & ATP synthesis \\
\hline $\begin{array}{l}\text { Respiratory supercomplex factor } 1 . \\
\text { mitochondrial }\end{array}$ & RCF1 & Mitochondrial biogenesis \\
\hline Enolase 1 & ENO1 & $\begin{array}{l}\text { Glycolytic } \\
\text { pathway-Growth }\end{array}$ \\
\hline Nitrate reductase & YNR1 & Nitrate assimilation \\
\hline Stationary phase protein 4 & SPG4 & Stationary phase \\
\hline Heat shock protein SSB1 & SSB1 & $\begin{array}{l}\text { Protein biosynthesis. } \\
\text { Stress response }\end{array}$ \\
\hline \multicolumn{3}{|l|}{ DECREASE } \\
\hline GTP-Binding Protein 1 & GTP1 & Protein syntesis \\
\hline Kinetochore protein Nuf-2 & NUF2 & Cell division \\
\hline Peptidyl-prolyl cis-trans isomerase 9 & CYP9 & Protein syntesis \\
\hline Acyl-CoA-binding protein 2 & ACB2 & Protein transport \\
\hline Meiotically up-regulated gene 97 protein & MUG97 & Cell division \\
\hline $\begin{array}{l}\text { Cytochrome c oxidase subunit } 4 . \\
\text { mitochondrial }\end{array}$ & COX4 & ATP synthesis \\
\hline $\begin{array}{l}\text { Endoplasmic reticulum transmembrane } \\
\text { protein } 2\end{array}$ & YET2 & Protein transport \\
\hline Protein MTH1 & MTH1 & $\begin{array}{l}\text { Glucose transport. signal } \\
\text { transduction }\end{array}$ \\
\hline Nucleoside diphosphate kinase & NDK1 & $\begin{array}{l}\text { ATP synthesis. } \\
\text { Nucleotide metabolism }\end{array}$ \\
\hline Prefoldin subunit 2 & GIM4 & Protein folding \\
\hline
\end{tabular}

oral candidiasis, we isolated various C. albicans strains from renal transplant recipients. A phagocytosis assay was performed and the highly hypha-forming strain $111 \mathrm{R}$ presented the lowest 




FIGURE 2 | Murine model of oral candidiasis. (A) Macroscopic lesions of candidiasis on the tongue dorsum characterized by pseudomembranous white plaques in mice infected with Candida albicans untreated with Eugenia uniflora extract (Group I). (B) Aspect of lesion on the tongue dorsum in an animal infected with Candida albicans grown overnight in the presence of E. uniflora EAF (1,000 $\mu \mathrm{g} / \mathrm{mL}$;Group II), showing a remarkable reduction of confluent lesions on mucosal surface.



FIGURE 3 | Direct examination of a biological sample collected from the oral cavity of mice infected with Candida albicans 111R untreated with Eugenia uniflora extract-Group I (A), and (B) Candida albicans 111R strain previously grown in the presence of Eugenia uniflora EAF (1,000 $\mu \mathrm{g} / \mathrm{mL})$ - Group II. Black arrow indicates a long true hypha characteristic of Candida albicans 111R strain. White arrow shows a reduction of hyphal size. Asterisk indicates oral epithelial cells, in higher proportion in Group I rather than Group II. Optical microscopy, 400× of magnification.

number of phagocytized C. albicans cells (11 phagocytized cells in 100 PMNs), while the other isolates were highly phagocytized. This fact reflects the importance of filamentation against the action of phagocytic cells, corroborating the idea that the emission of a long germ tube is a crucial factor to escape the immune system.

Fradin et al. (2005) described that when incubated in the presence of PMNs (in whole blood and plasma), 95.6\% of $C$. albicans cells are still in the form of blastoconidia, $38 \%$ of these cells are phagocytized, while $57.5 \%$ are bound to PMNs after 30 min incubation. Based on these data, the strain 111R was not effectively phagocytized due to the fact that when previously grown in NGY broth, this strain already presents a large number of hyphae formed, even at a temperature that does not stimulate filamentation. Thus, when incubated in the presence of PMNs, cells were not efficiently phagocytized.

On the other hand, for most of the strains, a significant reduction occurred in the number of Candida cells phagocytized 


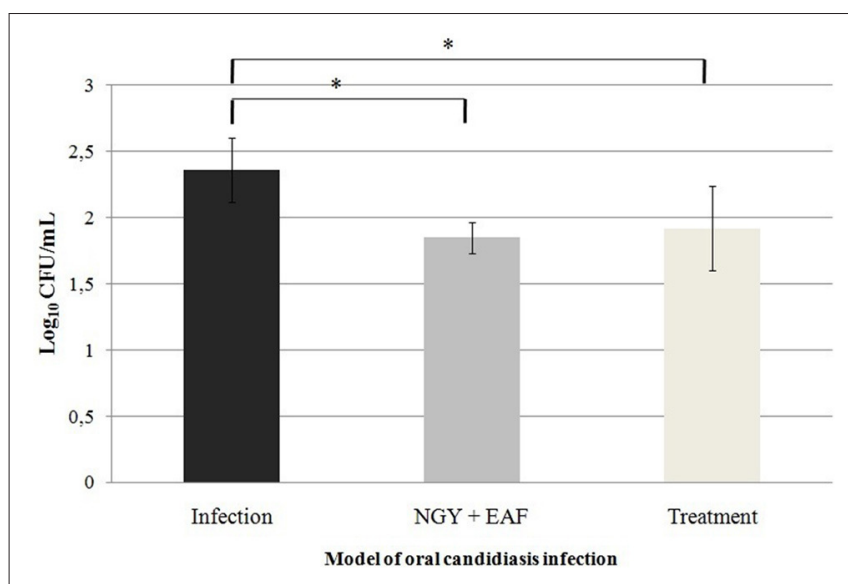

FIGURE 4 | Mean values and standard deviations of the number of CFU/mL of Candida albicans 111R recovered from lesions on the tongue dorsum of mouse in murine model of oral candidiasis. Samples were seeded on SDA, incubated at $37^{\circ} \mathrm{C}, 48 \mathrm{~h}$. *Significant difference between the number of $\mathrm{CFU} / \mathrm{mL}$ recovered from the animals of the different groups of infection, $P<0.05$.

by the PMNs, if previously grown in the presence of the fraction. This finding reinforces our hypothesis that the E. uniflora EAF is acting on the C. albicans cell wall of due to the fact cells were previously grown in the presence of the referred natural product. Therefore, some probable accumulation of components of the EAF in the cell wall may impair PMNs recognition and interaction with $\beta$ - glucans, mannan and mannose receptors, which are part of the constitution of the cellular wall, and recognized by pattern recognition receptors (PRPs) found on the surface of defense cells (Gow et al., 2012; Erwig and Gow, 2016).

Our unexpected results of PMNs phagocytosis reduction after treating Candida cells with E. uniflora does not invalidate our natural product as a possible antifungal drug in the future, because others have found the same effect with amphotericin $B$ and this is still a very broad spectrum and highly effective antifungal drug used in the clinical practice (Pallister et al., 1992).

Our proteomics analysis revealed that most of the proteins expressed were related with Protein Metabolism (23.1\%) and Energy (17.9\%). This fact is possibly related with the morphogenesis assay, because protein synthesis is highly necessary to the process of transition from yeast to hyphae, as well as ATP synthesis to provide energy for the construction and elongation of the cell wall of C. albicans is another crucial step (Dudek et al., 2013).

In the presence of the EAF of E. uniflora, proteomics analysis showed that eight proteins were overexpressed, including Pam16. The transport of preproteins into the mitochondrial matrix depends of the association of Presequence Translocase of the Inner Membrane (TIM23) and Presequence TranslocaseAssociated Motor (PAM) which is a complex of proteins that form an aqueous channel for the transport of presequencecarrying preproteins into the mitochondrial matrix, and the PAM complex includes the Pam16 protein (Li et al., 2004). In this complex, the Pam16 function is to form a stable complex with
Pam18 and antagonize this protein in its function of promoting the regulation of ATPase activity of mtHSP70 protein in the mitochondrial matrix (Dudek et al., 2013). The overexpression of Pam16 suggests a reduction in the metabolism of C. albicans cells in the presence of the fraction because it is a negative key regulator acting directly in Pam 18 reducing ATPase function.

F1F0-ATPase complex beta subunit (Atp2) is a cell surface protein (Gil-Bona et al., 2015) associated with ATP synthase complex proteins, participating in the process of cell respiration and energy. In a study of proteome profiling of $C$. albicans (Monteoliva et al., 2011), a reduced expression of Atp2 in the differentially detected proteins related with the respiration process in the yeast-to-hyphae transition was described. Ebanks et al. (2006) investigated C. albicans yeast and hyphal cell wall and associated proteins by proteomics, and observed that Atp2 and Enol were down regulated during the hyphal stage, when compared with yeast forms. This fact may explain the reason why both proteins are overexpressed in our cells treated with the EAF that cause a reduction in filamentation.

Enolase 1 (Eno1) is an important protein of C. albicans involved in several biological functions (Silva et al., 2014). The main function of Enol is in the glycolytic pathway, where it catalyzes the conversion of 2-phospho-D-glycerate to phosphoenolpyruvate, which is critical in both glycolysis and gluconeogenesis (Ko et al., 2013). Enolase 1 also participates in several biological functions, as a heat shock protein involved in thermotolerance and growth (Silva et al., 2014), suggesting that the high expression of Enol in our treated cells could be a compensatory mechanism of C. albicans to survive to the adverse condition of the E. uniflora EAF associated with the incubation at $37^{\circ} \mathrm{C}$.

Several proteins were down-regulated in the presence of the E. uniflora EAF and the main biological processes associated with these proteins were protein synthesis and transport (Gtp1, Cyp9, Acb2, Yet2), ATP synthesis (Rcf1, Ndk1 and Cox4), Cell division (Nuf2, Mug97), Glucose transport (MTH1) and Protein folding (Gim4). The biological processes affected by the reduction of these proteins could be related to the formation of fragile and damaged cells, with reduced metabolism and difficult growth.

The Kinetochore protein Nuf2, which is associated with cell division, was down-regulated in our treated cells. Kinetochore is a protein complex machine localized on the centromere of each chromosome. The primary function of kinetochore is to lead to the attachment of the chromosome to the dynamic plus ends of spindle microtubules. This is an important step in the segregation of chromosomes (Roy et al., 2013). It is also related with the formation of heterochromatin and maintenance of cohesion between sister chromatids until anaphase onset and is also involved in the recruitment of the spindle assembly checkpoint machinery to prevent cell cycle progression if an error persists (Roy et al., 2013). In fact, if there are failures on the kinetochore machinery either by repeating a subunit proteins or lacking ones, the interaction of kinetochore-microtubules in meiosis organization may result in aneuploidy due the unequal distribution of chromosomes (Joglekar et al., 2008). Therefore, our cells may be unable to properly complete cell cycle, compromising all cellular metabolisms. 

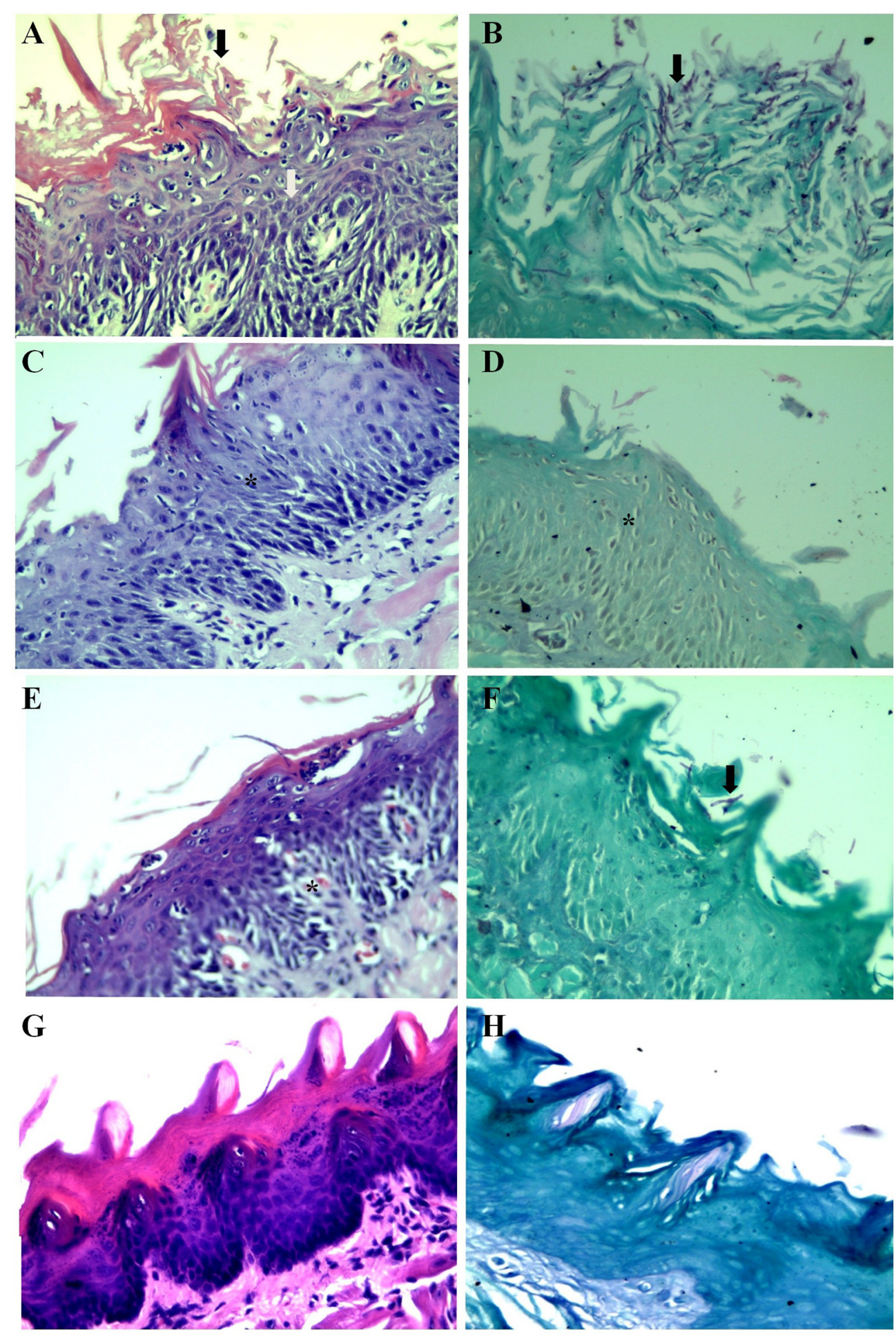

FIGURE 5 | Histopathological analysis of the dorsum of the tongue of mice. (A) Group I, HE, Stratified squamous mucosa with acanthosis, spongiosis, severe neutrophilic exocytosis (white arrow) and erosion of the epithelium (black arrow). (B) Group I, PAS, Stratified squamous mucosa exhibiting numerous corneal layer and pseudohyphae and true hyphae (filamentous structures) of fungi (black arrow). (C) Group II, HE, Stratified squamous mucosa with acanthosis, spongiosis and mild exocytosis (asterisk). (D) Group II, PAS, Stratified squamous mucosa without evidence of fungi (asterisk). (E) Group III, HE, Stratified squamous mucosa with mild acanthosis, spongiosis and mild exocytosis (asterisk). (F) Group III, PAS, Stratified squamous mucosa with rare short pseudohyphae black arrow) (G,H) Normal squamous mucosa without evidence of lesions and fungi. 


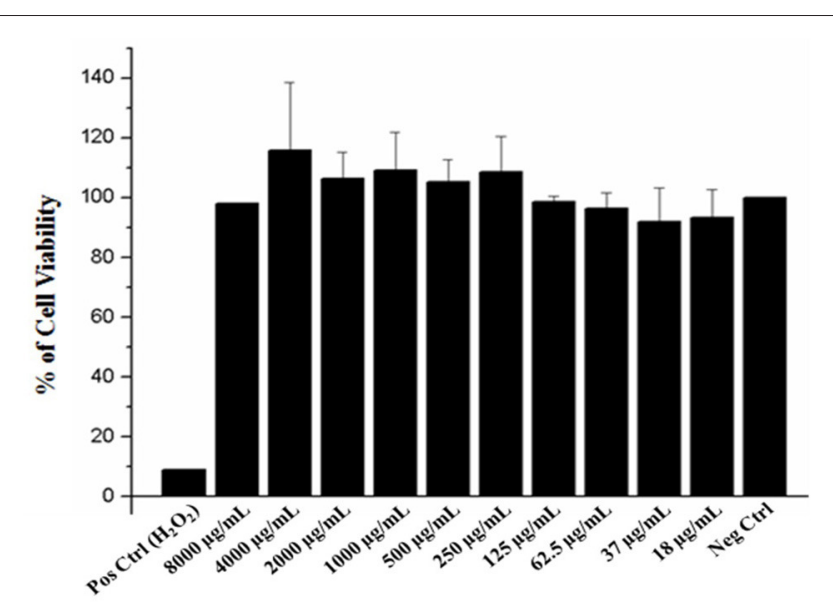

FIGURE 6 | Effect of the EAF of Eugenia uniflora on A549 cell line viability determined by MTT assay. Pos Crtl (control); tested concentrations of the extract $(8,000-18 \mu \mathrm{g} /)$. The samples were analyzed in three independent experiments performed in duplicate.

Cytochrome C oxidase subunit 4 (Cox4) belongs to the electron transport chain in C. albicans (Schmidt et al., 2010; Mick et al., 2011). Cox4 expression was reduced in our treated cells. These results are in agreement with Gil-Bona et al. (2015), which found that Cox 4 was more found in hyphae rather than budding cells, corroborating with the fact that filamentation was reduced in our cells treated with the natural product.

Several proteins are involved in the organization of cytoskeleton during C. albicans morphogenesis, an essential step that contributes to yeast-to-hyphae transition (Millan-Zambrano and Chavez, 2014). Prefoldin was down regulated in our treated cells. This is a multi-subunit complex protein containing six polypeptides with molecular mass ranging from 14 to $23 \mathrm{kDa}$ (two $\alpha$-subunits and four $\beta$-subunits) (Simons et al., 2004; Millan-Zambrano and Chavez, 2014). Prefoldin is responsible to the important function of bind to native and unfolded tubulin and actin and delivery to Chaperonin-containing T-complex polypeptide-1 (CCT), the protein responsible to the folding of these proteins and its assembly into high-order protein structures, such as microtubules and actin filaments, which are essential to the cytoskeleton organization (Millan-Zambrano and Chavez, 2014).

In order to investigate the in vivo effect of the EAF of $E$. uniflora, a murine model of oral candidiasis was established with the $111 \mathrm{R}$ strain pre-cultivated in the presence and absence of the natural product. When the infection was established with C. albicans untreated cells (control), the presence of a confluent pseudomembranous white plaque on the tongue surface, typical of the oral candidiasis lesion was observed (Millsop and Fazel, 2016). These lesions were significantly reduced when Candida cells were pre-cultivated in the presence of the E. uniflora EAF, because the animals presented slightly white spots dispersed on the tongue surface and absence of macroscopic lesion. The reduction of lesions agreed with the findings at the direct examination. C. albicans cells obtained from Group I animals presented aggregates of long fungal filaments associated with large cell desquamation, observed by the presence of numerous epithelial cells in direct examination. The presence of visually shorter hyphae and the reduction of epithelial desquamation were observed in previously treated cells as well as when the infection was established and then the EAF was administered on the tongue surface. The macroscopic reduction of lesion aspect and reduction of presence of hyphae and viable cells was confirmed with the Colony Forming Units (CFU) assay. In the presence of the E. uniflora extract, there was a significant reduction in C. albicans CFU growth.

The reduction in CFU counting observed in our study reflects the action of the EAF of E. uniflora in C. albicans, causing damage to the cells and death, which was reflected in the reduction of CFU in both conditions tested and may be directly linked to initial impairment to form hyphae during the experiments in vivo.

In order to evaluate the essential oil of Melaleuca alternifolia for the treatment of oral candidiasis induced in an immunosuppressed mouse model, de Campos Rasteiro et al. (2014) induced oral candidiasis in the same condition of the present study and after the establishment of infection, the essential oil was administered on the tongue surface. C. albicans cells were recovered from the tongue with a sterile swab and it was observed a significant reduction of CFU counting when the essential oil was administered, indicating the lethal effect of the Melaleuca alternifolia on infection by C. albicans. However, its main component terpinen-4-ol was less efficient than fluconazole to treat mice with experimentally induced oral candidiasis, where no yeast colonies were recovered and tongue lesions were not detected (Ninomiya et al., 2012).

The extract of North American ginseng (Panax quinquefolius L.) in C. albicans disseminated infection was evaluated by administering the extract in the animal's drinking water in a $1 \%$ solution provided to mice for ad libitum ingestion $48 \mathrm{~h}$ before experimental infection. Heart, Brain and both kidneys were recovered for C. albicans culture. The efficacy of the Panax quinquefolius extract was observed by the higher survival of animals and reduction im CFU counting, mainly in the kidneys (Trammell et al., 2012). Therefore, our results strongly suggest that E. uniflora impairs proper hypha formation in C. albicans and this phenomenon may reflect directly in pathogenesis which may be observed in the decrease of CFU counting in yeast treated cells.

The reduction of hypha formation by C. albicans $111 \mathrm{R}$ observed in vitro (Silva-Rocha et al., 2015) was confirmed in vivo in the present study. Our histopathological findings corroborate with the macroscopical lesion analysis, because in the animals where the infection was established with $C$. albicans cells pretreated with the EAF of E. uniflora, the reduction of filamentation was also observed in both $\mathrm{HE}$ and PAS staining examination and consequently, tissue damage was reduced. The same findings were observed in the study of de Campos Rasteiro et al. (2014) using the essential oil of $M$. alternifolia in oral candidiasis. In this study, the essential oil was also capable to considerably reducing the invasion of $C$. albicans on the tongue tissue and it 
was evidenced by the observation of fewer lesions in the animals when compared with the control group.

In order to evaluate cell viability and ensure the safety of use of E. uniflora the EAF in human cells, a MTT assay was performed using an epithelial lung cell line A549 and the cell survival rate was very high, with more than $90 \%$ of the viable cells in the concentration of $8 \mathrm{mg} / \mathrm{mL}$ and this fact may reflect safety of the EAF that may be used in the future as an antifungal compound.

Several studies are performed to analyze the safety of natural products extracts with antimicrobial activities by MTT. Recently, de Oliveira et al. (2017) evaluated the biological activities of Rosmarinus officinalis L. (rosemary) extract (25, 50, and 100 $\mathrm{mg} / \mathrm{mL}$ ) in C. albicans, Staphylococcus aureus, Enterococcus faecalis, Streptococcus mutans and Pseudomonas aeruginosa cells. It was observed that it was necessary a concentration over than $50 \mathrm{mg} / \mathrm{mL}$ of the extract to reduce $40 \%$ of the cell viability using human gingival fibroblasts (FMM-1), human breast carcinoma cells (MCF-7), and cervical carcinoma cells (HeLa).

Madeira et al. (2016) evaluated the Cymbopogon citratus (i.e., lemongrass) extract in C. albicans cells and cytotoxicity was analyzed by MTT using peripheral blood mononuclear cells (PBMCs) collected from healthy human volunteers. It was observed that a reduction of $40 \%$ of viability occurred when the cells were treated with $10 x M I C$. In the same way, other natural products have been considered of low toxicity, our findings have shown that the EAF of E. uniflora may be safe for the application in the prevention or treatment of C. albicans superficial infection.

\section{CONCLUSIONS}

The emergence of new therapeutic alternatives for the treatment of oral candidiasis is necessary and the use of natural products has increased recently. The findings demonstrated in the present study suggest that the EAF of E. uniflora acts on the cell wall of C. albicans, interacting directly with important proteins involved in the structural organization of C. albicans morphology and essentials pathways of metabolism, which can be reflected in the damage to its structure, reducing filamentation, which made cells defective and unviable. This fact is reflected with the significant reduction of lesions observed macroscopically on

\section{REFERENCES}

Amorim, A. C., Lima, C. K., Hovell, A. M., Miranda, A. L., and Rezende, C. M. (2009). Antinociceptive and hypothermic evaluation of the leaf essential oil and isolated terpenoids from Eugenia uniflora L. (Brazilian Pitanga). Phytomedicine 16, 923-928. doi: 10.1016/j.phymed.2009.03.009

Becker, K. L., Ifrim, D. C., Quintin, J., Netea, M. G., and van de Veerdonk, F. L. (2015). Antifungal innate immunity: recognition and inflammatory networks. Semin. Immunopathol. 37, 107-116. doi: 10.1007/s00281-014-0467-z

Biasi-Garbin, R. P., Demitto Fde, O., Amaral, R. C., Ferreira, M. R., Soares, L. A., Svidzinski, T., et al. (2016). Antifungal potential of plant species from brazilian caatinga against dermatophytes. Rev. Inst. Med. Trop. Sao Paulo. 58:18. doi: 10.1590/S1678-9946201658018

Bradford, M. M. (1976). A rapid and sensitive method for the quantitation of microgram quantities of protein utilizing the principle of protein-dye binding. Anal. Biochem. 72, 248-254. doi: 10.1016/0003-2697(76)90527-3 animal's tongue, as well as in the reduction of invasion and tissue damage, observed with histopathologycal analysis. In addition, in human cells, even at concentrations eight times above the concentration used in the present study, the E. uniflora EAF did not show cellular cytotoxicity, which probably makes it safe for administration in human cells. Thus, the EAF of E. uniflora may be a potential new therapeutic agent for the treatment of superficial candidiasis in the future.

\section{ETHICS STATEMENT}

This study was carried out in accordance with the recommendations of Law number 11,794, of October 8, 2008, of Decree number 6,899, of July 15, 2009 and with the regulations issued by the National Council for Control of Animal Experimentation (CONCEA) of the ETHICS COMMITTEE IN THE USE OF ANIMALS (CEUA), Federal University of Rio Grande do Norte. The protocol was approved under the number $034 / 2015$.

\section{AUTHOR CONTRIBUTIONS}

WS performed the phenotypic tests, proteomics analysis and murine model experiments, analyzed data and prepared the manuscript. MdA performed animal experiments, MF and LS obtained and provided the E. uniflora EAF, JdS performed the MTT assay and supported MALDI-TOF analysis. TS and EM isolated and identified C. albicans strains, KR performed histopathological analysis, AU supported with protein extraction purification and bidimensional gel electrophoresis, $\mathrm{MM}$ and AF supported MALDI-TOF analysis, GC designed all tests and prepared the manuscript. All the authors approved the final manuscript.

\section{ACKNOWLEDGMENTS}

We are very grateful to the Conselho Nacional de Desenvolvimento Científico e Tecnológico (CNPq) grant Edital Universal 14/2011 and to the Coordenação de Aperfeiçoamento de Pessoal de Nível Superior (CAPES) grant PROCAD CAPES NF-2008 for financial support.

Carlisle, P. L., and Kadosh, D. (2013). A genome-wide transcriptional analysis of morphology determination in Candida albicans. Mol. Biol. Cell 24, 246-260. doi: 10.1091/mbc.E12-01-0065

Chaves, G. M., Bates, S., Maccallum, D. M., and Odds, F. C. (2007). Candida albicans GRX2, encoding a putative glutaredoxin, is required for virulence in a murine model. Genet. Mol. Res. 6, 1051-1063.

Chaves, G. M., and da Silva, W. P. (2012). Superoxide dismutases and glutaredoxins have a distinct role in the response of Candida albicans to oxidative stress generated by the chemical compounds menadione and diamide. Mem. Inst. Oswaldo Cruz 107, 998-1005. doi: 10.1590/S0074-02762012000800006

Chaves, G. M., Santos, F. P., and Colombo, A. L. (2012). The persistence of multifocal colonisation by a single $\mathrm{ABC}$ genotype of Candida albicans may predict the transition from commensalism to infection. Mem. Inst. Oswaldo Cruz 107, 198-204. doi: 10.1590/S0074-027620120002 00008 
Childers, D. S., and Kadosh, D. (2015). Filament condition-specific response elements control the expression of NRG1 and UME6, key transcriptional regulators of morphology and virulence in Candida albicans. PLoS ONE 10:e0122775. doi: 10.1371/journal.pone.0122775

Colombo, A. L., Guimaraes, T., Silva, L. R., de Almeida Monfardini, L. P., Cunha, A. K., Rady, P., et al. (2007). Prospective observational study of candidemia in Sao Paulo, Brazil: incidence rate, epidemiology, and predictors of mortality. Infect. Control Hosp. Epidemiol. 28, 570-576. doi: 10.1086/513615

Dantas Ada, S., Day, A., Ikeh, M., Kos, I., Achan, B., and Quinn, J. (2015). Oxidative stress responses in the human fungal pathogen, Candida albicans. Biomolecules 5, 142-165. doi: 10.3390/biom5010142

de Campos Rasteiro, V. M., da Costa, A. C., Araujo, C. F., de Barros, P. P., Rossoni, R. D., Anbinder, A. L., et al. (2014). Essential oil of Melaleuca alternifolia for the treatment of oral candidiasis induced in an immunosuppressed mouse model. BMC Complement. Altern. Med. 14:489. doi: 10.1186/1472-6882-14-489

Denizot, F., and Lang, R. (1986). Rapid colorimetric assay for cell growth and survival. Modifications to the tetrazolium dye procedure giving improved sensitivity and reliability. J. Immunol. Methods 89, 271-277. doi: 10.1016/0022-1759(86)90368-6

de Oliveira, J. R., de Jesus, D., Figueira, L. W., de Oliveira, F. E., Pacheco Soares, C., Camargo, S. E., et al. (2017). Biological activities of Rosmarinus officinalis L. (rosemary) extract as analyzed in microorganisms and cells. Exp. Biol. Med. 242, 625-634. doi: 10.1177/1535370216688571

Dudek, J., Rehling, P., and van der Laan, M. (2013). Mitochondrial protein import: common principles and physiological networks. Biochim. Biophys. Acta 1833, 274-285. doi: 10.1016/j.bbamcr.2012.05.028

Ebanks, R. O., Chisholm, K., McKinnon, S., Whiteway, M., and Pinto, D. M. (2006). Proteomic analysis of Candida albicans yeast and hyphal cell wall and associated proteins. Proteomics 6, 2147-2156. doi: 10.1002/pmic.200500100

Erwig, L. P., and Gow, N. A. (2016). Interactions of fungal pathogens with phagocytes. Nat. Rev. Microbiol. 14, 163-176. doi: 10.1038/nrmicro.2015.21

Ferrari, M., Fornasiero, M. C., and Isetta, A. M. (1990). MTT colorimetric assay for testing macrophage cytotoxic activity in vitro. J. Immunol. Methods 131, 165-172. doi: 10.1016/0022-1759(90)90187-Z

Ferreira, M. R. A., Santiago, R. R., Langassner, S. Z., Mello, J. C. P., Svidzinsk, T. I. E., and Soares, L. A. L. (2013). Antifungal activity of medicinal plants from Northeastern Brazil. J. Med. Plant Res. 7, 3008-3013. doi: 10.5897/JMPR2013.5035

Fradin, C., De Groot, P., MacCallum, D., Schaller, M., Klis, F., Odds, F. C., et al. (2005). Granulocytes govern the transcriptional response, morphology and proliferation of Candida albicans in human blood. Mol. Microbiol. 56, 397-415. doi: $10.1111 / j .1365-2958.2005 .04557 . x$

Gerlier, D., and Thomasset, N. (1986). Use of MTT colorimetric assay to measure cell activation. J. Immunol. Methods 94, 57-63. doi: 10.1016/0022-1759(86)90215-2

Gil-Bona, A., Parra-Giraldo, C. M., Hernaez, M. L., Reales-Calderon, J. A., Solis, N. V., Filler, S. G., et al. (2015). Candida albicans cell shaving uncovers new proteins involved in cell wall integrity, yeast to hypha transition, stress response and host-pathogen interaction. J. Proteomics 127(Pt B), 340-351. doi: 10.1016/j.jprot.2015.06.006

Gow, N. A., van de Veerdonk, F. L., Brown, A. J., and Netea, M. G. (2012). Candida albicans morphogenesis and host defence: discriminating invasion from colonization. Nat. Rev. Microbiol. 10, 112-122. doi: 10.1038/nrmicro2711

Görg, A., Obermaier, C., Boguth, G., Harder, A., Scheibe, B., Wildgruber, R., et al. (2000). The current state of two-dimensional electrophoresis with immobilized pH gradients. Electrophoresis 21, 1037-1053. doi: 10.1002/(SICI)1522-2683 (20000401)21:6<1037::AID-ELPS1037>3.0.CO;2-V

Hamill, R. J. (2013). Amphotericin B formulations: a comparative review of efficacy and toxicity. Drugs 73, 919-934. doi: 10.1007/s40265-013-0069-4

Herrero, E., Ros, J., Belli, G., and Cabiscol, E. (2008). Redox control and oxidative stress in yeast cells. Biochim. Biophys. Acta 1780, 1217-1235. doi: 10.1016/j.bbagen.2007.12.004

Jayatilake, J. A., Samaranayake, Y. H., Cheung, L. K., and Samaranayake, L. P. (2006). Quantitative evaluation of tissue invasion by wild type, hyphal and SAP mutants of Candida albicans, and non-albicans Candida species in reconstituted human oral epithelium. J. Oral Pathol. Med. 35, 484-491. doi: $10.1111 / \mathrm{j} .1600-0714.2006 .00435 . \mathrm{x}$
Joglekar, A. P., Bouck, D., Finley, K., Liu, X., Wan, Y., Berman, J., et al. (2008) Molecular architecture of the kinetochore-microtubule attachment site is conserved between point and regional centromeres. J. Cell Biol. 181, 587-594. doi: 10.1083/jcb.200803027

Ko, H. C., Hsiao, T. Y., Chen, C. T., and Yang, Y. L. (2013). Candida albicans ENO1 null mutants exhibit altered drug susceptibility, hyphal formation, and virulence. J. Microbiol. 51, 345-351. doi: 10.1007/s12275-013-2577-z

Laemmli, U. K. (1970). Cleavage of structural proteins during the assembly of the head of bacteriophage T4. Nature 227, 680-685. doi: 10.1038/227680a0

Li, Y., Dudek, J., Guiard, B., Pfanner, N., Rehling, P., and Voos, W. (2004). The presequence translocase-associated protein import motor of mitochondria. Pam16 functions in an antagonistic manner to Pam18. J. Biol. Chem. 279, 38047-38054. doi: 10.1074/jbc.M404319200

Lima, P. S., Casaletti, L., Bailão, A. M., de Vasconcelos, A. T., Fernandes, G. R., and Soares, C. M. (2014). Transcriptional and proteomic responses to carbon starvation in Paracoccidioides. PLoS Negl. Trop. Dis. 8:e2855. doi: 10.1371/journal.pntd.0002855

Madeira, P. L., Carvalho, L. T., Paschoal, M. A., de Sousa, E. M., Moffa, E. B., da Silva, M. A., et al. (2016). In vitro effects of lemongrass extract on Candida albicans biofilms, human cells viability, and denture surface. Front. Cell. Infect. Microbiol. 6:71. doi: 10.3389/fcimb.2016.00071

Marcos, C. M., de Oliveira, H. C., de Melo, W. C., da Silva, J. F., Assato, P. A., Scorzoni, L., et al. (2016). Anti-immune strategies of pathogenic fungi. Front. Cell. Infect. Microbiol. 6:142. doi: 10.3389/fcimb.2016.00142

Martínez-Gomariz, M., Perumal, P., Mekala, S., Nombela, C., Chaffin, W. L., and Gil, C. (2009). Proteomic analysis of cytoplasmic and surface proteins from yeast cells, hyphae, and biofilms of Candida albicans. Proteomics 9, 2230-2252. doi: $10.1002 /$ pmic. 200700594

Mick, D. U., Fox, T. D., and Rehling, P. (2011). Inventory control: cytochrome c oxidase assembly regulates mitochondrial translation. Nat. Rev. Mol. Cell Biol. 12, 14-20. doi: 10.1038/nrm3029

Millan-Zambrano, G., and Chavez, S. (2014). Nuclear functions of prefoldin. Open Biol. 4:140085. doi: 10.1098/rsob.140085

Millsop, J. W., and Fazel, N. (2016). Oral candidiasis. Clin. Dermatol. 34, 487-494. doi: 10.1016/j.clindermatol.2016.02.022

Monteoliva, L., Martinez-Lopez, R., Pitarch, A., Hernaez, M. L., Serna, A., Nombela, C., et al. (2011). Quantitative proteome and acidic subproteome profiling of Candida albicans yeast-to-hypha transition. J. Proteome Res. 10, 502-517. doi: $10.1021 / \mathrm{pr} 100710 \mathrm{~g}$

Mosmann, T. (1983). Rapid colorimetric assay for cellular growth and survival: application to proliferation and cytotoxicity assays. J. Immunol. Methods 65, 55-63. doi: 10.1016/0022-1759(83)90303-4

Muzyka, B. C., and Epifanio, R. N. (2013). Update on oral fungal infections. Dent. Clin. North Am. 57, 561-581. doi: 10.1016/j.cden.2013.07.002

Neuhoff, V., Arold, N., Taube, D., and Ehrhardt, W. (1988). Improved staining of proteins in polyacrylamide gels including isoelectric focusing gels with clear background at nanogram sensitivity using Coomassie Brilliant Blue G-250 and R-250. Electrophoresis 9, 255-262. doi: 10.1002/elps.11500 90603

Ninomiya, K., Maruyama, N., Inoue, S., Ishibashi, H., Takizawa, T., and Oshima, H. (2012). The essential oil of Melaleuca alternifolia (tea tree oil) and its main component, terpinen-4-ol protect mice from experimental oral candidiasis. Biol. Pharm. Bull. 35, 861-865. doi: 10.1248/bpb.35.861

Nucci, M., Queiroz-Telles, F., Alvarado-Matute, T., Tiraboschi, I. N., Cortes, J., Zurita, J., et al. (2013). Epidemiology of candidemia in Latin America: a laboratory-based survey. PLoS ONE 8:e59373. doi: 10.1371/journal.pone.0059373

Pallister, C. J., Johnson, E. M., Warnock, D. W., Elliot, P. J., and Reeves, D. F. (1992). In-vitro effects of liposome-encapsulated amphotericin B (AmBisome) and amphotericin B-deoxycholate (Fungizone) on the phagocytic and candidacidal function of human polymorphonuclear leucocytes. J. Antimicrob. Chemother. 30, 313-320. doi: 10.1093/jac/30.3.313

Patil, S., Rao, R. S., Majumdar, B., and Anil, S. (2015). Clinical appearance of oral Candida infection and therapeutic strategies. Front. Microbiol. 6:1391. doi: 10.3389/fmicb.2015.01391

Ramos, R. T. M., Bezerra, I. C. F., Ferreira, M. R. A., and Soares, L. A. L. (2017), Spectrophotometric Quantifcation of Flavonoids in Herbal Material, Crude 
Extract, and Fractions from Leaves of Eugenia uniflora Linn. Pharmacogn. Res. 9, 253-260. doi: 10.4103/pr.pr_143_16

Roy, B., Varshney, N., Yadav, V., and Sanyal, K. (2013). The process of kinetochore assembly in yeasts. FEMS Microbiol. Lett. 338, 107-117. doi: 10.1111/1574-6968.12019

Salvato, F., and Carvalho, M. C. C. G. (2010). Métodos e estratégias em proteômica e suas aplicações na área vegetal. Ciência Rural 40, 727-734. doi: 10.1590/S0103-84782010005000018

Samaranayake, Y. H., Cheung, B. P., Yau, J. Y., Yeung, S. K., and Samaranayake, L. P. (2013). Human serum promotes Candida albicans biofilm growth and virulence gene expression on silicone biomaterial. PLoS ONE 8:e62902. doi: 10.1371/journal.pone.0062902

Schmidt, O., Pfanner, N., and Meisinger, C. (2010). Mitochondrial protein import: from proteomics to functional mechanisms. Nat. Rev. Mol. Cell Biol. 11, 655-667. doi: 10.1038/nrm2959

Schumacher, N. S., Colomeu, T. C., de Figueiredo, D., de Campos Carvalho, C., Cazarin, C. B. B., Prado, M. A., et al. (2015). Identification and antioxidant activity of the extracts of Eugenia uniflora leaves. characterization of the anti-inflammatory properties of aqueous extract on diabetes expression in an experimental model of spontaneous type 1 diabetes (NOD Mice). Antioxidants (Basel) 4, 662-680. doi: 10.3390/antiox4040662

Sherman, R. G., Prusinski, L., Ravenel, M. C., and Joralmon, R. A. (2002). Oral candidosis. Quintessence Int. 33, 521-532.

Silva, R. C., Padovan, A. C., Pimenta, D. C., Ferreira, R. C., da Silva, C. V., and Briones, M. R. (2014). Extracellular enolase of Candida albicans is involved in colonization of mammalian intestinal epithelium. Front. Cell. Infect. Microbiol. 4:66. doi: $10.3389 /$ fcimb.2014.00066

Silva-Rocha, W. P., de Brito Lemos, V. L., Ferreira, M. R., Soares, L. A., Svidzisnki, T. I., Milan, E. P., et al. (2015). Effect of the crude extract of Eugenia uniflora in morphogenesis and secretion of hydrolytic enzymes in Candida albicans from the oral cavity of kidney transplant recipients. BMC Complement. Altern. Med. 15:6. doi: 10.1186/s12906-015-0522-x

Simons, C. T., Staes, A., Rommelaere, H., Ampe, C., Lewis, S. A., and Cowan, N. J. (2004). Selective contribution of eukaryotic prefoldin subunits to actin and tubulin binding. J. Biol. Chem. 279, 4196-4203. doi: 10.1074/jbc.M306053200
Solis, N. V., and Filler, S. G. (2012). Mouse model of oropharyngeal candidiasis. Nat. Protoc. 7, 637-642. doi: 10.1038/nprot.2012.011

Studier, F. W. (1973). Analysis of bacteriophage T7 early RNAs and proteins on slab gels. J. Mol. Biol. 79, 237-248. doi: 10.1016/0022-2836(73)90003-X

Trammell, R. A., Cox, L., Pikora, J., Murphy, L. L., and Toth L. A. (2012). Evaluation of an extract of North American ginseng (Panax quinquefolius L.) in Candida albicans-infected complement-deficient mice. J. Ethnopharmacol. 139, 414-421. doi: 10.1016/j.jep.2011.11.026

Tsang, P. W., Bandara, H. M., and Fong, W. P. (2012). Purpurin suppresses Candida albicans biofilm formation and hyphal development. PLOS ONE 7:e50866. doi: 10.1371/journal.pone.0050866

Victoria, F. N., Lenardão, E. J., Savegnago, L., Perin, G., Jacob, R. G., Alves, D., et al. (2012). Essential oil of the leaves of Eugenia uniflora L.: antioxidant and antimicrobial properties. Food Chem. Toxicol. 50, 2668-2674. doi: $10.1016 /$ j.fct.2012.05.002

Yarrow, D. (1998). "Methods for the isolation, maintenance and identification of yeasts," in The Yeasts, A Taxonomic Study, 4th Edn., ed C. F. J. Kurtzman (Amsterdam: Elsevier Science), 77-100.

Younes, S. S., and Khalaf, R. A. (2013). The Candida albicans Hwp2p can complement the lack of filamentation of a Saccharomyces cerevisiae flo11 null strain. Microbiology 159(Pt 6), 1160-1164. doi: 10.1099/mic.0.06 $7249-0$

Conflict of Interest Statement: The authors declare that the research was conducted in the absence of any commercial or financial relationships that could be construed as a potential conflict of interest.

Copyright (c) 2017 Silva-Rocha, de Azevedo, Ferreira, da Silva, Svidzinski, Milan, Soares, Rocha, Uchôa, Mendes-Giannini, Fusco Almeida and Chaves. This is an open-access article distributed under the terms of the Creative Commons Attribution License (CC BY). The use, distribution or reproduction in other forums is permitted, provided the original author(s) or licensor are credited and that the original publication in this journal is cited, in accordance with accepted academic practice. No use, distribution or reproduction is permitted which does not comply with these terms. 